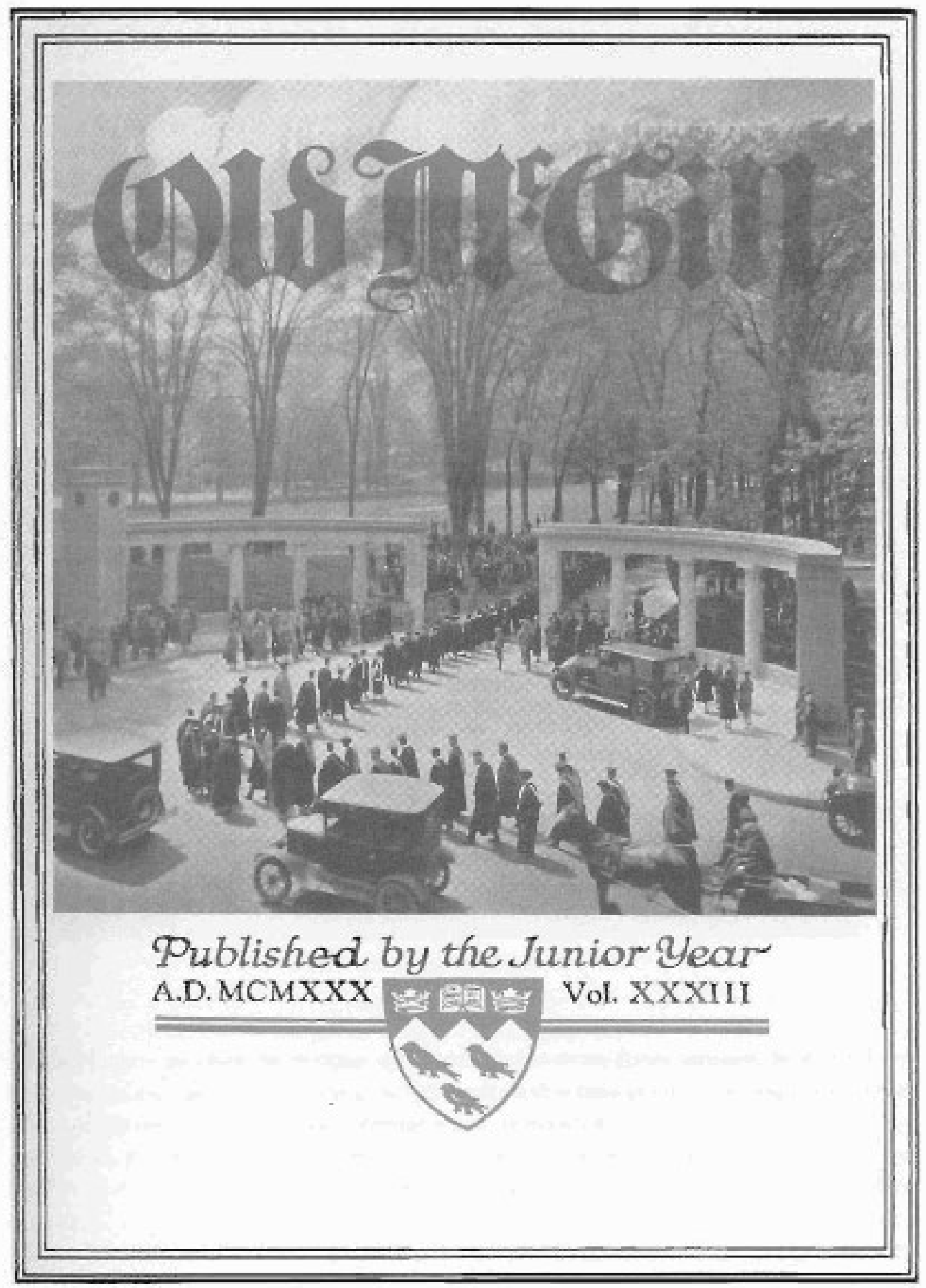

Figure 1. Procession at Roddick Gates, ca. 1930. 


\section{THE GATES OF MCGILL: AN UNPUBLISHED NOVEL OF THE 1920'S BY "DINK" CARROLL}

\section{By Robert H. Michel}

Austen (Dink) Carroll (McGill Law 1923) was a well-known Montreal sportswriter from the 1940s to the 1980s. Early in his career, he also wrote fiction. This article quotes and summarizes Carroll's unpublished novel about student life at McGill University in the 1920s, placing the story within its McGill context and the college novel genre. In his novel of a McGill student's rites of passage, Carroll combined experience with invention. Against a realistically drawn McGill and Montreal background, Peter, the novel's protagonist, goes through the archetypal experiences of many North American university students in the 1920s. He plays football, lives in a fraternity, cuts classes, discovers campus intellectuals and the world of ideas, and Montreal's taverns, brothels and bustling international port. Carroll left his partly autobiographical novel unfinished; this article suggests a nonfictional conclusion in the form of a postscript about Dink Carroll's career after graduation.

L'Université d'il y a soixante-quinze ans reprend vie dans un roman inachevé et non-publie du rédacteur sportifmontréalais, Austen (Dink) Carroll. Le roman suit son héros, Peter Rice, durant sa première année d'études en arts a McGill tandis qu'il joue au football, devient membre d'une fraternité, lit les écrivains modernes, découvre Montréal et apprécie la liberté de la vie étudiante dans les années 1920. Cet article permet de découvrir ce roman non publié sous une forme abrégée et éditée dans laquelle on trouve la citation de passages mémorables, un résumé assez précis de la trame du roman, qui le situe dans son contexte historique mcgilllien, et un post-scriptum de Carroll lui-même.

\section{INTRODUCTION}

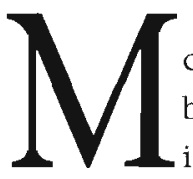

cGILL SEVENTY-FIVE YEARS ago comes back to life in an unpublished, unfinished novel by Montreal sports writer, Austen "Dink" Carroll. The novel follows its protagonist, Peter Rice, during his first year in Arts at McGill as he plays football, joins a fraternity, reads modern writers, explores Montreal, and enjoys the free life of students in the 1920s. The strength of this unknown work lies in its atmospheric descriptions of the McGill campus, Montreal, football practice, and a freshman's exposure to diverse influences. The purpose of this article is to let this unpublished novel speak for itself, in an edited, shortened form, by quoting some memo- rable passages, closely summarizing its plot, placing it in its McGill historical context, and rounding out the unfinished story with a postscript on Carroll himself. Quotations have been chosen for their McGill or Montreal interest and importance to the plot; they generally follow the order in which they appear in the narrative so that Carroll's story unfolds at the same time. Since the novel lacks a title, one is proposed here: "The Gates of McGill," evoking McGill's trademark Roddick Gates (built in 1925, which Peter sees on arrival, Fig. 1) as well as the novel's perception of the University as a place apart - deliberately chosen, entered, and one day left. To bring 
Carroll's McGill alive in images as well as words, places and people in the novel (real and imaginary) are illustrated by contemporary photographs and art. It seemed appropriate to complement a novel about a MCGill student in the 1920 s with student artwork of the same era in issues of Old McGill.

This unfinished novel consists of 114 type-written pages; it is held among Carroll's papers in the McGill University Archives. In 1920, after a year at the University of Toronto, Carroll came to McGill, where he played football brilliantly, joined a fraternity, Zeta Psi, and took his degree in Law in 1923, but did not practise. From the 1930s to the 1980s, he wrote about hockey, football, baseball, boxing, golf, salmon fishing, and sports characters, mainly for the Montreal Gazette, but also for the Saturday Evening Post, Liberty, and Maclean's. He had played the sports he wrote about; admired Hemingway, the prototype novelist-athlete-journalist; and was friends with writer Morley Callaghan. After graduating from McGill, Carroll may have hoped to be a novelist rather than a journalist. In one of his unpublished stories, Joe, a recent graduate of McGill, boards at his old fraternity one summer and tries to write short stories or a novel but has trouble getting started. In the 1930s, and probably the 1940s, Carroll wrote many short stories, mainly depicting Montreal or sports. One, "The Amateur," was published by Esquire in January 1936; his other fiction, mainly unpublished, is in his archive.

In one of Carroll's stories (ca. 1930s), a character declared: "What I really should have done instead of becoming a copywriter was to have written a novel based on undergraduate life. This I should have done the first year I was out of college, like F. Scott Fitzgerald." 2 As it turned out, Carroll began just such a work - a McGill novel - before he found his destiny as a sports journalist with a novelist's eye. Carroll could draw on his own McGill past for Peter Rice's football and fraternity life. But like most writers, Carroll extended his protagonist's experiences beyond his own. Peter, unlike Carroll, an Arts student, plunges into all the archetypal university activities: bullsessions, drinking bouts, and the discovery of new ideas and friends. Inspired by Montreal's steamy reputation, Peter and his friends go to a brothel, exposing the alluring degradation of this rite of passage in the days of the double standard. Carroll set his novel around 1927 or 1928, several years after his own student days. He probably wrote it in the 1930s. (The typescript's dating is discussed with other details in the Note at the end.)

Carroll's story, and this summary, may appeal mainly to McGill's community, but the novel also stakes a modest claim for McGill in the Fitzgeraldesque college novel genre, which offered an ideal

\footnotetext{
1 The novel is in the McGill University Archives, Austin "Dink" Carroll Papers, MC 4151, C2, file 1. There are also about 20 short stories. Some of Carroll's papers, focusing on correspondence with Morley Callaghan, were described in Robert Michel, "The Austin 'Dink' Carroll Papers in the University Archives," Fontanus, VI (1993): 149-56. In addition to Carroll's unpublished literary manuscripts, which include vignettes of the Montreal advertising business, the McGill Archives holds sporadic runs of Carroll's correspondence, usually about sports. The papers include some photographs, but mainly they consist of original textual records, ca. 1930-1990; about 1.5 metres in extent. The Trent University Archives holds correspondence from Carroll in the A.).M. Smith Fonds (78-007, Correspondence " $\mathrm{C}$ " 1963-1977). A sample of Carroll's magazine articles includes: Liberty, 5 Mar. 1938; The Saturday Evening Post, 8 Jan. 1938 ("The Hard Harrys of Hockey"); and Maclean's, 1 July 1943 (on Montreal fighter Johnny Greco). The story about Joe is in the Carroll Papers, MG 4151, C.1, file 2, untitied.

2 Carroll Papers, MG 4151, C.2, file 4, untitled vignettes, possibly for a novel set in advertising. Carroll meant Fitzgerald's This Side of Paradise (1920), set autobiographically at Princeton. Carroll might also have been influenced by Fitzgerald's later writing on college life in the Basil and Josephine stories published in the Saturday Evening Post around 1930-1931, which enshrined scenes of football and courting at Princeton and Yale, republished in Fitzgerald, The Basil and josephine Stories, ed. J. Bryer and J. Kuehl, 1973. In Fitzgerald's The Great Gatsby (1925), the character Tom Buchanan had been "one of the most powerful ends that ever played football at New Haven - a national figure in a way, one of those men who reach such an acute limited excellence at twenty-one that everything afterwards savours of the anticlimax" (Macmillan Publishing Co., New York, 1988), 6. Football as life's high point is also enshrined in Irwin Shaw's classic "The Eighty-Yard Run," (Esquire, January 1941); its protagonist recalls a football practice in the 1920 s as the high point of his life, which has gone down hill ever since.
} 
forum to discuss ideas, sports, ambition, social mobility, and romantic trials. "College" as used here comprises the American sense of post-secondary education - what Canadians call "university." College novels show how their authors experienced or imagined student life. Not all such authors actually attended college. Those who, like Carroll, had gone to the institutions they portrayed brought authenticity to their stories. From 1900 to 1940 (the period influencing Carroll), many writers fed the public's avid interest in college life, as philanthropy, state funding, prosperity, and an increasing demand for technological training multiplied colleges and students in the United States and Canada. Among others, Thomas Wolfe, Willa Cather, Carl van Doren, George Santayana, Dorothy Canfield, Irving Stone, and S.V. Benet wrote college novels. Compiling a bibliography of American college novels through 1979, John Kramer defined college novels as those in which colleges and universities were a crucial part of the setting and included students or staff as main characters. ${ }^{3}$ Hundreds of novels have been set at Harvard, Yale, Princeton and other actual or fictional American colleges. Likewise, British writers have made an industry out of the Oxbridge genre since the days of Tom Brown, Verdant Green, and Julian Home, 140 years ago. For their part, as American authors do with
Harvard, Canadian writers attach the recognisable McGill label to any off-the-rack character who can read and write, litigate or heal. But while McGill probably appears in fiction more often than any other Canadian university, it rarely does so in much detail. In contrast, Carroll's work fulfils Kramer's definition of a college novel; McGill provides the setting and main characters. Moreover, Peter Rice's odyssey offers a realist counterpart to two satires of McGill by McGill professors: Stephen Leacock's famous Arcadian Adventures with the Idle Rich (1914) and Regis Messac's unknown Smith Conundrum (1942). Messac's novel, like Carroll's, is set at late-1920s McGill, but from the point of view of a professor vainly trying to teach dim, frivolous students. Coincidentally, the fullest nonfictional memoir of McGill student life - Campus Shadows (1946) by Harold Trott (M.D. McGill, 1924) - also is set around the same time, $1920 .^{4}$

Carroll wrote Peter Rice's story in the third person past tense, revealing Peter's thoughts, but no one else's. For emphasis, quotations of Carroll's text are given in italics, (followed by their source pages within parentheses). For clear differentiation between Carroll's text (phrased in the past tense) and the rest of the article, editorial summary of the plot is phrased in the present tense.

3 The genre of novels set at universities and colleges is examined by John O. Lyons, The College Novel in America (Carbondale, Illinois: Southern Illinois University Press, 1962); Ben Siegel, ed., The American Writer and the University (Newark: University of Delaware Press, 1989); Mortimer R. Proctor, The English University Novel (Berkeley: University of California Press, 1957). John E. Kramer, Jr., The American College Novel: an Annotated Bibliography, (New York: Garland Publishing, 1981), is a valuable reference work covering novels published up to 1979. Kramer excluded works with sexual themes as their main rationale - the college novel subculture of luridly-covered paperbacks popular from the 1940s to the 1970 s about stuffy profs learning from sexy students, which confirmed the worst fears of those who did not attend university. Accordingly, he left out the best seller, Harrad Experiment, by Robert Rimmer, 1966 - about free love at an imaginary offshoot of Harvard.

4 Leacock and Messac are discussed in Robert Michel, "Floreat Plutoria: Satirical Fiction about McCill," Fontanus, IX (1996): 29 45, 81-86; Harold W. Trott, Campus Shadows (Hemlock, New York: Crosset and Williams, 1946). Shorter recollections by 1920 s students are included in E. A. Collard, ed., The McCill You Knew (Toronto: Longman, Canada, 1975), including "The immortal 'Shag'", 89-94. For historical background see Stanley B. Frost, McCill University, for the Advancement of Learning, 2 vols. (Montreal: McGillQueen's University Press, 1980-1984); Margaret Gillett, We Walked Very Warily (Montreal: Eden Press Women's Publications, 1981); Ian Pilarczyk, A Noble Roster: 150 Years of Law at MCGill (Montreal: McGill University Faculty of Law, 1999). A notable socialist attack on every aspect of American college culture, ca. 1920 - sports, capitalist control, lack of academic freedom, even pseudo-mediaeval college architecture, is Upton Sinclair's The Goose-step, rev. ed., (Pasadena: California, 1923). 


\section{FALL: FOOTBALL AND FRATERNITY}

The story starts with Peter, still a Toronto-area high school student, resolving to attend McGill after he watches McGill's football team beat Toronto. ${ }^{5}$ After the game, he meets the McGill coach, "Frank Connelly," modelled on McGill's real coach, the legendary Frank "Shag" Shaughnessy. Both wear soft hats and long overcoats, are big and tanned, have huge hands, huge voices, invent new plays and coach unbeatable teams. Three years later, Peter comes to McGill. By now he is attracted not just by football, but by Montreal; he rejects humdrum Toronto:

In his schoolboy world of quickly shifting values, the emphasis was not now entirely on football. He had been too long already in Toronto. The place was familiar and unexciting. Even with the new liberty he would have as an undergraduate, the city held little appeal for him. Whole sections of it were beautiful, but its life was uninteresting. After eleven o'clock at night, its streets were as deserted as the main street of a boom town when the gold fever has passed. 'A big bush town' someone had called it, describing its sprawling regularity. It was a city of homes and quiet friendships, a city for settled, mature people, not for the 20th Century young who can exist on excitementalone. Wasn't Montreal the most romantic, as well as the largest city in the Dominion? Weren't its inhabitants an entirely different variety of the genus homo? Wasn't it an ocean port, with a floating, cosmopolitan population? (prologue, pp. 3-4)

Peter arrives by berth car, dreaming of football. Since most Montrealers were French, he decides he will learn French. He looks out as his train approaches Windsor Station:
He saw the smoke of factories against the leaden sky. Then the horizon grew abruptly attemuated, and the backs of houses appeared; they were passing through the crosssection of slum district that greets travellers entering any large city. Curious speculations about the next four years stirred in his mind. He guessed he expected a great deal from them. The tendency of older men to speak with scarcely concealed sentimentality about college had not escaped him. There must be a reason for it. (p.2)

Peter takes a taxi to McGill, his new home, impeded by nearly as much traffic as we have today.

He had his first eager glimpse of the city. He was sensitive to colour and, in the slanting rain, the city's tone appeared to be grey. There were varying shades, but that was the basic colour. They circled around a square [Dominion], bordered by huge sandstone edifices: cathedrals [St. James the Great] and hotels [the Windsor] by the look of them. On all sides of the square were the picturesque hansom cabs of another era, now disappeared from the streets of most cities. The patient horses looked shrunken in the rain. They were in the middle of heavy traffic, and at a corner where the tram lines intersected, they halted momentarily. Straight ahead, back of the city, stood the mountain. It dominated the whole scene... The life of the city seemed to struggle up towards the huge hill. They moved again, past a smart hotel [The Mount Royal, opened in 1922], and up to a wide street [Sherbrooke], where the driver made a right turn. All the houses were built of the same coloured stone, very close together, giving the effect of terraces that extended for solid blocks. He had never seen anything like it except in pictures of some parts of New York and certain European cities. (p.3)

\footnotetext{
5 Peter Rice's attraction to McGill for its football is paralled in real life by the remark of Norman Levine (who like Carroll studied at McGill and set several stories at McGill) that seeing the McGill Redmen play football helped him choose McGill: "Why I am an expatriate," Canadian Literature 5 (Summer 1960): 52. An early, gory encounter between McGill and Toronto appears in Ralph Connor's The Prospector (Toronto: McClelland and Stewart, 1904). However, this was a case of the McGill name being useful for novelists. In his autobiography, Connor declared the bloody match was based on one his Toronto rugby football team had played in the 1880 s, not against McGill, but "with a band of savage Irishmen from Ottawa College who played to win regardless of rules and regulations and reckless of life and limb, their own or their enemy's." See Charles W. Gordon, Postscript to Adventure: the Autobiography of Ralph Connor, New York: Farrar and Rinehart, 1938), 43. Thus reality traduces art.
} 


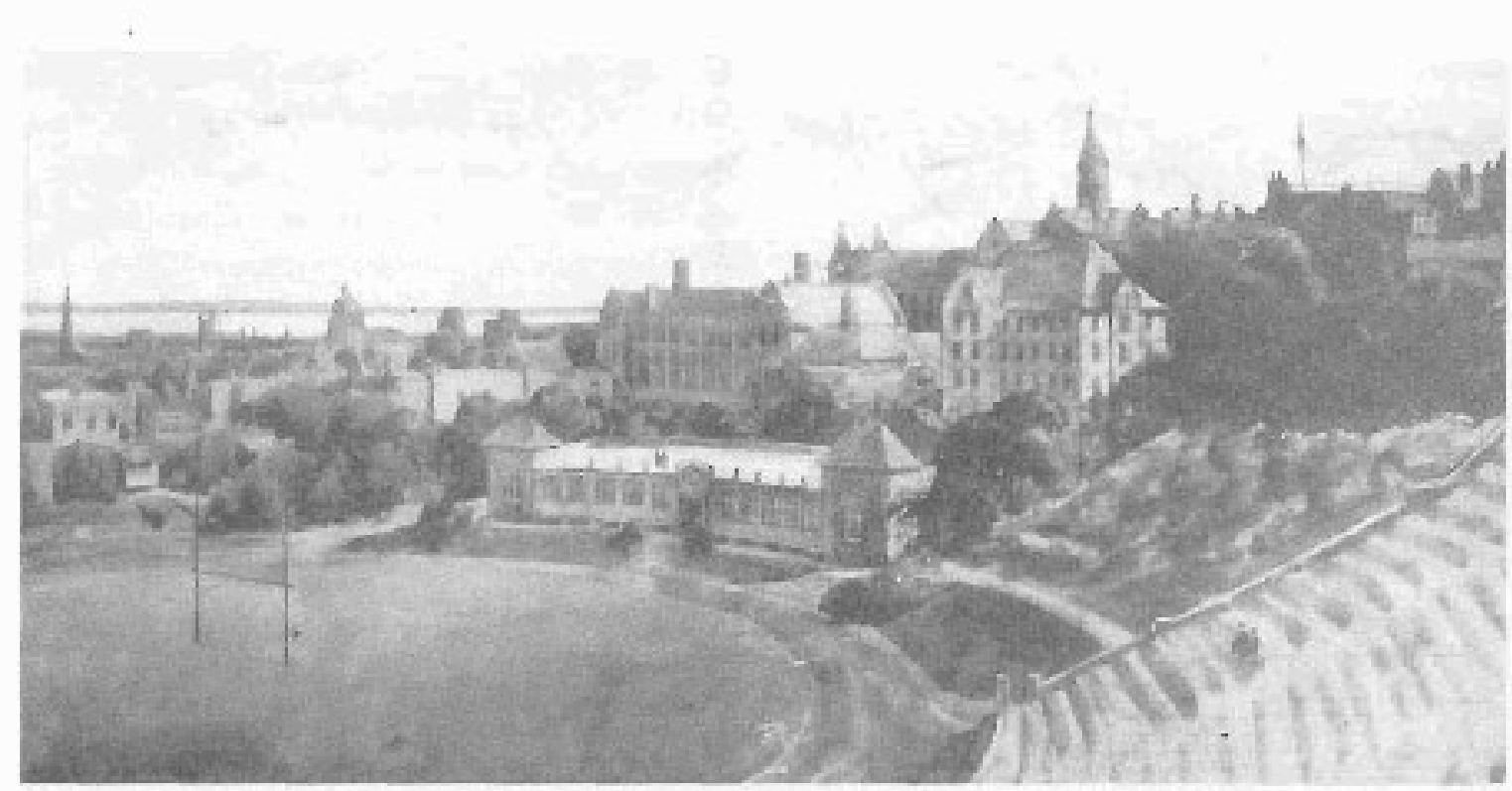

Figure 2. Field House and Molson Stadium, ta. 1921.

Peter's taxidrops him at the Student Union [now the McCord Muscum of Canadian History]. Actoss the road was the Uniwersiry with its old greystone butidings and huge elms: the campus in Septembet.

At first, ine wizs conscious anly of is benutifiti sife - nesthins at the late of the morntain. Than he noticed the lash sreen turf of the campzos, the rad cky conih caurs and the toweving elms ipiented by irincipal Dawson sixly years beiorc]. Elobovate semiteinctular pales of stone, with a small clock twer at one end stood at the cuibafice to the grotmils, and itw sprending branches of the timas an either side of the road loding ap from the gates fonsed a green camopy overiterd. The digrity of age, the solidith of stane and the propitan? youth of green grass and greon trees were elements that sonschow thamanized in the pictase $(\mathrm{p}, 3)$

The Rotdick Gotes, which Peter has just seen, were screscent of modemized baric cotumns built in 1225 its memory oi Medir,al Frofessor Sir Thomas Roddick. The Gates immediatcly became the eampus symbol.
As the main entry to the campus, they still notify those walking or driving through them that they are. entering a separate kingdom of knowiedge.

Peter goes into the Student Union and ienmedi-

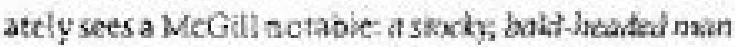
witt? a Ifvid sim acress one cheek. This is Major Colos jin eeal life, Majer Stexan Forbes, maneger of athlex. tos, former ste: of foocball and otive sempres ac Moith, 1907-J9 1, wa: heco and exertplat of sports ss the training grousd for life and the buttlefield!, ${ }^{2} \mathrm{Next}$, Peter sees Coach Connelly at breakiast readistg a papec Connelly tells him to get a tray of breakfast and ioln him. How much does he weigh? One humbrat and filty pounds. What poxicion dit he play? backficid. Conselly atuises Petez to get a room in onte of the rooming houses on tiniwerkity Sucet and not to reth the landtady he will not stay long fic assumes leter will foin a fratertiry soan. GAs yot McGilt had no men's residence, although ies Royal Victoris College providesó stumptuous lodgings for woinen stucien(s.) Jeter finds a hosse with a "Chambre a louer" sign and takes a thont for fixe

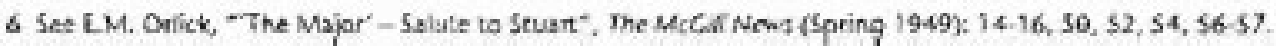


dollars a week. Later he climbs the hill for his first football practice. The field is above the campus, on the mountain's shoulder:

He thought the Molson Stadium was the most beautiful thing of its kind he had ever seen (Fig. 2). It seemed to be carved right out of the side of the mountain, the concrete stands rising sheer against it at the same violent angle. Back of the field house... were the massive buildings of Royal Victoria Hospital (Fig. 3). Many an injured hero was wheeled to the window of his sickroom of a Saturday afternoon, from which vantage point he watched sadly and impotently the tide of battle as it ebbed and flowed. Through the wooden fabric of the bleachers on the open side of the field, he could see the city below - flat rooftops, avenues of trees, the bare network of electric signs, curved church domes and jutting spires, and the isolated superstructures of half a dozen skyscrapers. But there was something in the crisp, clear altitude of the field, in its glorious setting, that made him think vaguely of the Greek stadia of the old Olympiads... This was the proper setting for football heroics. (pp.6-7)

The spectators' stands were on the north side of the playing field, looking south across McGill and the city to the St. Lawrence River, a view later largely blocked by a south stand and high rise buildings. Molson Stadium had opened in 1919, a memorial to McGill graduate Percival Molson (B.A. 1901), who had excelled at sports, won the Military Cross, fell in battle in 1917, and like Major Forbes symbolized the blood ties between prowess and courage in sports and war - ties re-enforced again in 1939, when the long-awaited gymnasium, built to serve as an armoury as well, was dedicated to the memory of McGill's war dead and McGill Principal Sir Arthur Currie, Canadjan Commander in the First World War. It was first used as a drill hall, as the Second War began; a war memorial room was added after 1945. To return to the gym-less 1920s: Peter practices with the team, under Coach Connelly's gentle encouragement:
'Football's a driving game and you gotta drive them,' declares Connelly. Practices would be tough, Peter realizes. The routine included a turn at the bucking machines, heavy box-like structures loaded down with blocks of cement and mounted on coasters. The linemen pushed these up and down the field in short, hard charges. Then came the bucking straps, held on each side by a player, with a padded noose in the centre just large enough to allow a plunging back to thrust his head through. The sandbags followed. A dozen of these bags stood in a line about five yards apart and the player threw himself across the first bag, scrambled to his feet, picked up speed and hurled himself at the next bag. Then, dizzy and reeling, he had the privilege of setting them up for the next man. The tackling dummy was another delight. Standing next to the dummy, Connelly roared: 'Hit it! don't pet it! Stay on your feet and tear into it! Hurt it! Knock it cockeyed!' Assisted by former players, he supervises every exercise: 'Good God, you couldn't break into a conservatory with that sort of a charge,' he chided a sweating aspirant at the bucking machine. 'Get some leg drive! Push! Now-go!'Practice finishes with some start-andstop sprinting. Connelly encourages an exhausted, slow-responding player: 'Careful there, Buster. You'll step on a shoelace and break your neck!.' (p.8)

Connelly's famous original, "Shag" Shaughnessy, had captained the Notre Dame football team in 1904 and was a non-practicing law graduate like Carroll. McGill hired him in 1912 to give professional coaching. He was Canadian football's first American import. The first Canadian university to use professional coaching, McGil], like other universities, used football to win prestige and alumni support. Shaughnessy always argued that team sports inspired the entire University; he introduced the training table, where athletes ate together and built team spirit. Shaughnessy not only coached but also publicized and interpreted football to the McGill audience by writing in the student annuals and the Mocill News. To students and the public, he was better known than any other McGill staff member, except Political 


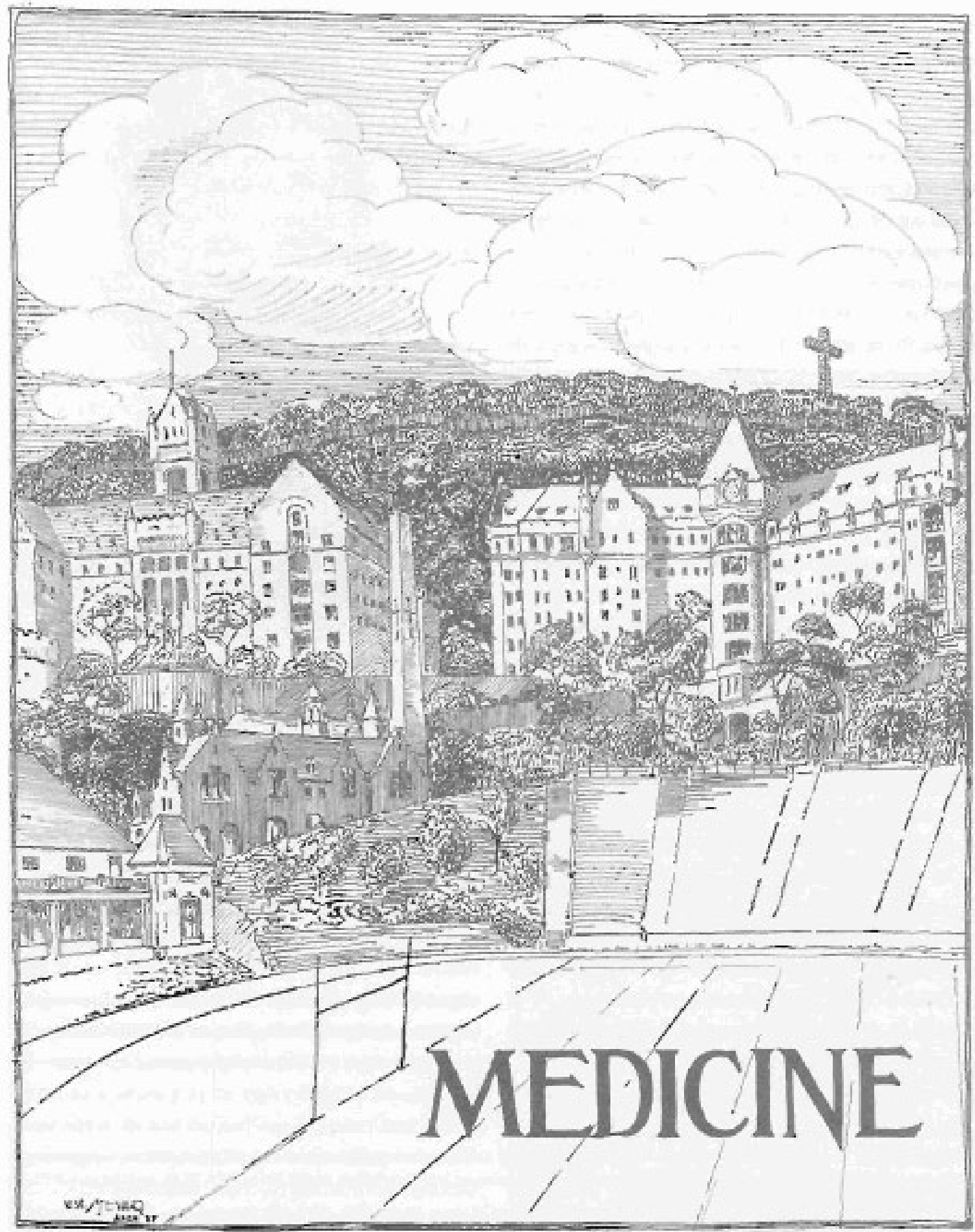

Fugure 3. This was the proper serting for football heroics. Foorball field, Molson Stadium, Royal Victoria Hospltal and Mount Royal, by N.M. Stewart, Arch. 1927. 
Economy Professor Stephen Leacock and Principal Sir Arthur Currie. While Leacock was known for bis peculiar but gentle wit, Shaughnessy was famous for sarcasm. In 1921 a McGill law student, Frank Genest, (LL.B 1921), published a little book about a McGill student just off the farm called Si Whiffletree; on meeting $S i$ in the Union, Shag says: "Greetings haystack, when did you get in - on the last load of huckleberries?" Covering football for the McGill Daily, Whifletree watches Shag coaching: "puttin' his bevy of retinin' young society buds through the hoops. He was handin' out so dum many compliments that the hull team was blushin' up like a burlesque queen on bein' asted what was her age by the Census man."

Shaughnessy and Carroll (Figs. 4,5) became lifelong friends. Besides the portrait rendered through Connelly, Carroll wrote about Shaugbnessy's techniques in nonfictional articles: "If he thought a playet was dogging it, he didn't hesitate to give him a tongue lashing and order him to do a few extra laps around the track...." Dissidents complained this might be all right for professional spork, hut college foothall was supposed to be fun In the 1920s, Canadian footbal! tept some fearures of Englisin Rugby: it also diftered from American football. Shatrghnessy described the Cansdian gamc as " 7 rambination of bucks, passfng runs and lots of kicking. " acsides introducing innovations in blocking and other strategies, Shaughnessy long advocated the forwatd pass, which had opened up and enlivened Ametican footbail. St:atsghnessy iniroduced the forward pass in an extsibition match with Usiversity of Syractie at McGill in 1921; it revolutionized the Canadian game when is was fin,ally adopied in 1931.8

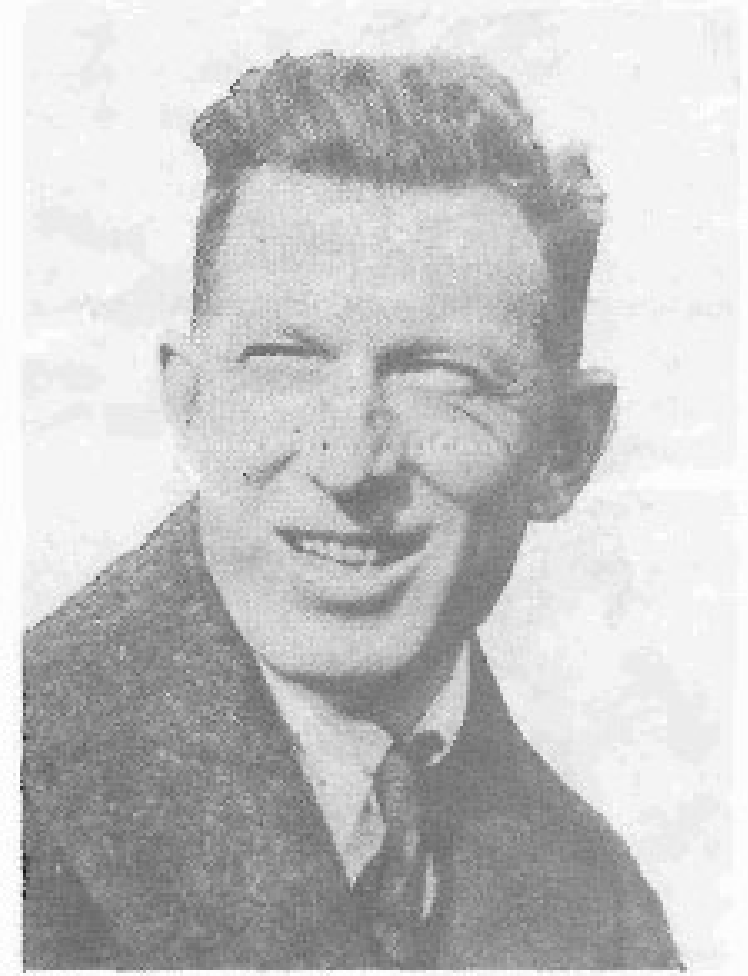

Figure 4, Coach Frank "Shag" Shaughnexsy.

Meanwhile, Peter and his tcammates stould be rejutred to leatn how to explokt the extsting rules effectively: After practice, Peter and the other players telax in the clubby atmosphere of the locbor toom:

If the fteld weas solenur with sertons porpase, the fich house was mad arth the spirit of fin. Ut was a mation? ietdenvan affer the strain of practice. There wats a great

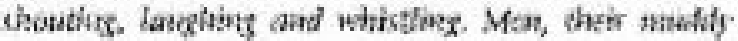

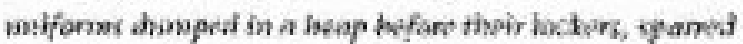
with each other in their bintivdat suets. Sicam form the

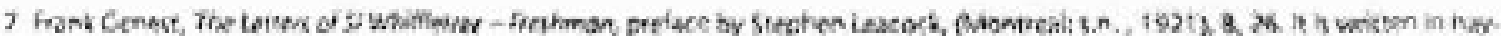

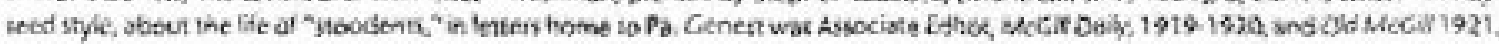

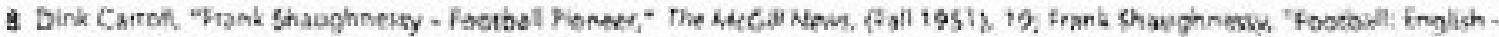

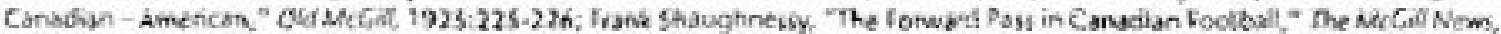
12 , no. 4 (September 1931) 19.20 . The continuing differences between American and Canad an foothal were dikerssed by Ter

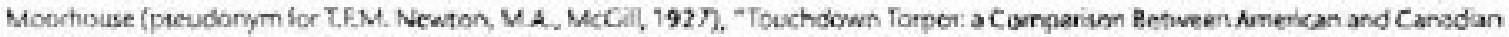
footbali and Some Siaggestiens tor Each," The McGalf News, 19, no. 2 (Spring 1938): 15.39, 63-6e. See dys Frank Conseritino,

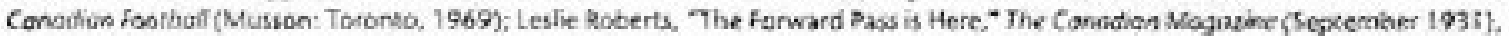
12, 32: Robers, "Americamaing' Canadian Sport," The Canofion Mognzine (Nevernber 1931), 8, 4 ?. 
hot showers closded the mirrors and cloaked the room in a mist. Someone threw a giass of cold water over the top of a shower and the irate accupant emerged and pulled tw bench out from under thret or four innocent onlookers. One chap, anxious to get away, had progressed in his dressing to the point where he staod combing his hair before a spot he had carefully wiped in the frosted mirror. Several times, men passing to and from the showers had nen demestating hands over the parted hair. With a philiosopher's patience, he rammed his hat down on the wet, rangled mass and departed. Even Connelly mibent. Smiling, he went from man to man, inquiring how they feit. He instructed the trainer to take particular care with the men who had been scrimmaging. He seemed to have a private wad for everyone. (pp.9-10)

Connelly (like the real coach, Shaughnessy) wants the players to build up loyalties and friend. ships; he makes sure Peter meets the other men. Peter becomes friendly with his teammate Don Horwill, who lives in a flat west of MCGill; soon they will join the same fraternity. We learn Peter is laking Arts. He wanders down to St. Catherlne's Street to eat at the popular chaln testaurant, Chlld's. (While not wealthy, he never seems to lack funds.) Back at his boarding house, he ponders his future apprehensively and writes his mother that he has found a room (his father is dead, we learn later; there is nothing more about Peter's (amily). Later he reads Dreiser's Sister Canie (foreshadowing his later fascination with novels):

As he read the account of Carrie's strange fight with Hurstwad to Monitreal, and of her bewliderment in that alien cily, his own feeling of unreality deepened. Lying an his back, staring at the high ceiling in the old-fashioned house, he had the haif-scared feeling that he was beglaning an entirely new life in which noching was familiar... A fow weeks later, when the fall term had officially begun, he looked back with wander at his frightemed uncer. tainty during those first few days. (p.12)

Peter makes the football team easily. He excels (as Carroll had) at punting. He can kick the bail farther, highes, and more accurately than any mon on the sapud (p. 14). His picture appears in the McGiti Daily; he is already a celebrity. He eats suppez at the football training tabic, which features steaks, milk, toast and high calorics for energy. There are detailed descriptions of football practice and Conneliy's chalk taiks at the biackboard in the dining room for an hour and a half, after training dinners, shooting questions at hall-asleep players. Peter reslizes Conneliy lives for football, corresponding far and wide to keep up with deveiopments actoss the continent. If a new play was incroduced in, say, Caltfornia, he would be explaining it a week later to his own tean. The first game approaches. Former players, now distinguished in the City, begin to show up at the training table, urging the players to uphoid their traditions. Practices attract spectotors. There is a rumout that a stranger is taking notes on the plays. Connelly and Major Coles close the stadium to keep out spies. To open the season, McGill will meer Queen's (Toronto

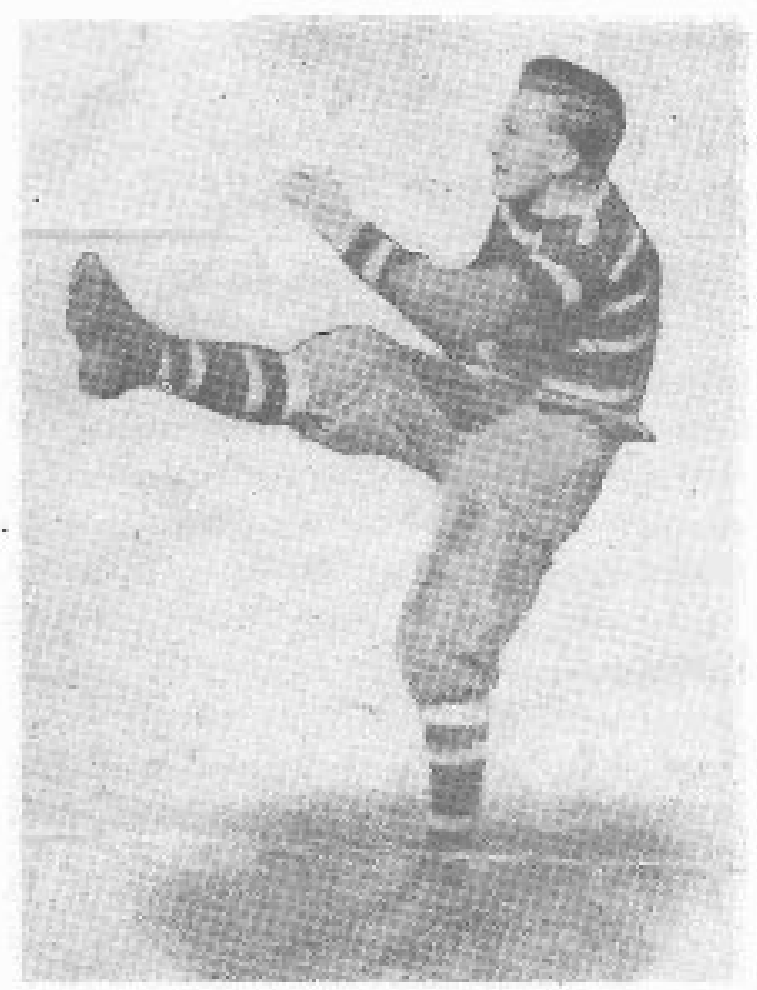

Figure 5. Austin "Dink" Carroll on the McGIII Football Team ca. 1921. 
is the other great rival). The night before the game, Connelly gives a pep talk:

If you don't know the plays by now, you'll never know 'em. We've only gotta few. I kept'em simple purposely... plays don't mean much. Fundamentals mean everything... Make your own breaks and watch for 'em!... About blocking-if every man takes the man he's supposed to take outta the play-well, we'relong gone! (pp.17-18)

Pep talks like Shaughnessy's may have doubled in importance after 1921, when the Canadian rules banned coaching from the sidelines during games in order to force the players to decide their own tactics. The Queen's students are already on the campus; their team stays at the glamorous new Mount Royal Hotel. The press waits to see Connelly; McGill football is big news in Montreal. A pep rally is in swing in the Student Union. Peter has trouble sleeping, afraid he will fumble. The next day, the team gathers at the Student Union before the game. Connelly sees Peter is nervous:

'Come over here, son.' He put a kindly asm around his shoulders and led him to the window.' Listen. I know how you feel. You're that type-temperamental. The other kind you gotta kick awake. There'll be another game tomorrow and the day after that and the day after that. Lots more games, see? I'm not expectin' miracles. All I want is for you to gimme your best... A crowd's memory is damn short. You're a hero today if yuh win - and a bum tomorrow if yuh lose. So to hell with 'em all. Go out there and play the best game you know how.' (pp.21-22)

Then the team walks up University Street past the old greystone houses, up the hill to the stadium, past police at every corner, cars jammed together, girls in tams with streamers flying, boys carrying rugs, fraternity men on their door steps. The air was as light and heady as wine. Connelly gives them a final speech: 'A team that won't be beaten can't be beaten,' Connelly said grimly. 'There's only one way you can disgrace the university, disgrace yourselves and disgrace me. That's by goin' out there and layin' down.' (p.23) (It sounds like marching into battle, with Connelly taking over the role of the Spartan mothers who told their sons to return with their shields or upon them.) On field, the referee says something about the new rules (the rules were constantly changing and debated in Canada and the United States), the band plays God Save the King, and the kick-off comes straight at Peter:

At the right moment, he made a mechanical movement with his hands, the ball nestled in the basket formed by his arms and ribs, and he started forward. Impelled solely by instinct, he evaded the first two tacklers and sped along until an end, cutting across the field, lifted him clear off the ground in a crashing tackle... That tackle was like a dive in a clear, cool lake. He came up, his head clear as a bell, his nervousness miraculously gone. (p.24)

Although Connelly had doubted that Peter could stand up to heavy tackling, Peter now establishes himself as a ball carrier as well as a punter. McGill scores in the second quarter. At half-time the men lie on blankets sucking oranges while Connelly points out their mistakes; they are lucky Queen's is so terrible! But McGill goes on to win. There was jubilation in the field house. Everyone was absurdly light-hearted and light-headed. It was a luxury to be able to undress deliberately, step under the warm shower, stretch out on the rubbing table and have the soothing fingers of a trainer knead liniment into tired muscles. Peter had had his baptism of fire and had come through nobly (p.26). The team gets a night off the training table. Connelly warns them not to go wild. Peter and some others go to the Mount Royal Cafeteria for steaks. On the way home Peter reads about his punting in glorious terms in the late papers.

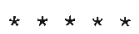

Besides making the football team (Fig. 6), Peter chooses a fraternity. Peter's picture and biographi- 


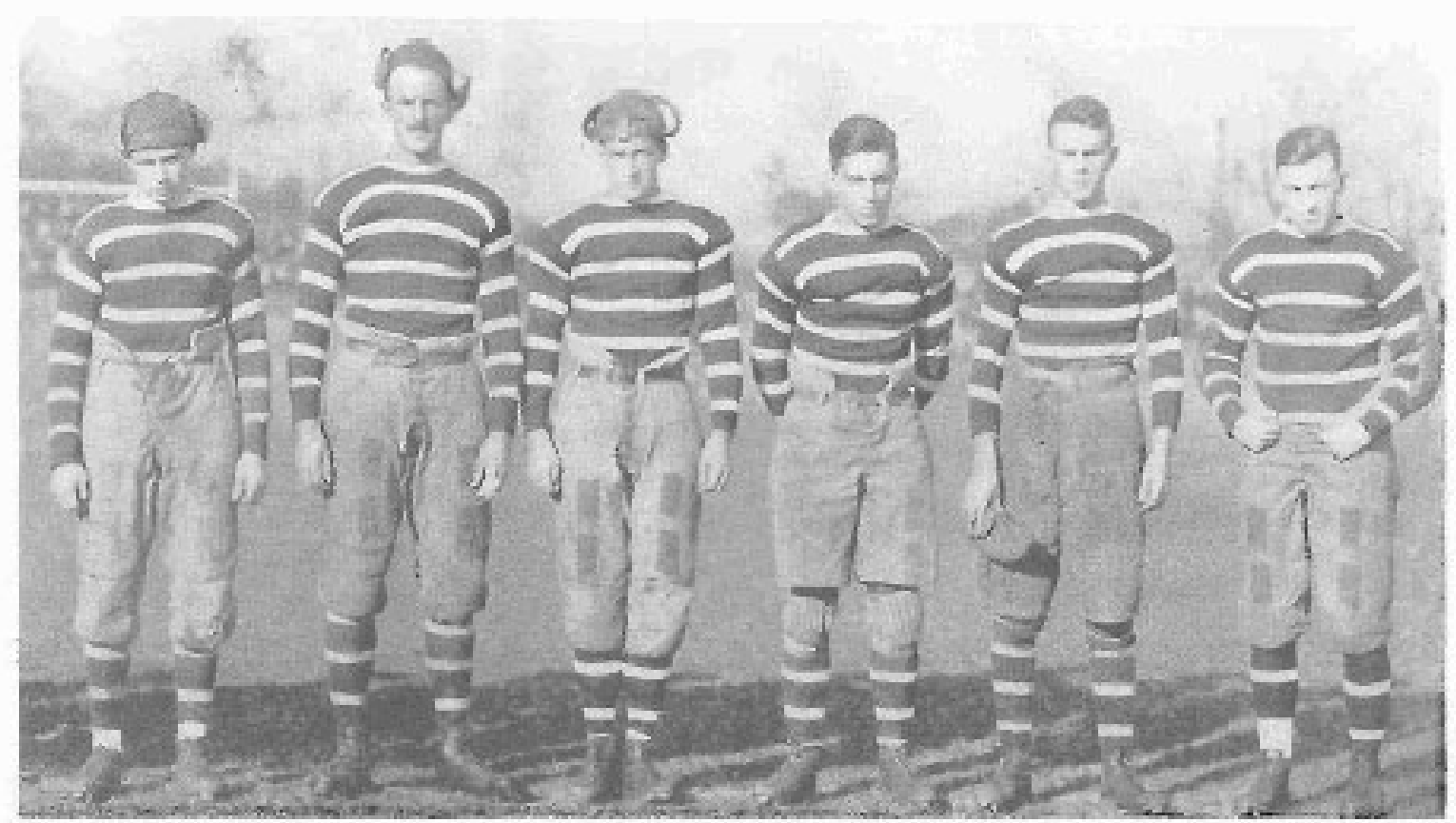

Figure 6. MeGill Football team (partial), Dink Cartoll at far right, 1921.

cal sketch had already appeared in the McGill Daily (Canada's oldest student daily, founded in 1911). As one of the cejebrifies in his class, Peter is nashed by scvera] fratcmities. At McGill as elsewhere, the athlete, especially the tootball player, was hailed as a M.M.O. (Big Man On Campus). Though Peter ests at the football training table in the evening, he ioreak. fasts and lunches at the varjous fraternity houses:

He met so nany men he couldn' hape to remenbernames. Gradually, he came fo idlontify certain fats with one or noo individlats, for it the conficsion of faces ane ar nus ahways stood out. There were six or seven fredmen tike himself. who were being rushed by the sanse frats, and he becane more familiar with them than with his hosts. (p.13)

Fraternities usually sought graduates of the private preparatory scbools. Although Peter's schoolIng was less posh, his football prowess conquers all;

The fellows most sought after were those who had cane up from the RMC [Royal Military College, Kingston] or the preparatory schools: $5 t$. Andreses, Epser Canada College, Trinity College Schuols, Bishop Ridley College,
Ashbry and Lemoxville. All of them had someone alsead of them, school friends of former years, who were laking care of their social furtures. The buik of the high school clonent, ambitions but bewildered, didn's have a chanse. An accasiandi one of their nmber, and Peter fall into this category, enty displayed some special falent that augued prominewace. Then they became part of the charmed circle considered the elite of the class. (p. .3)

Indeed, football could be the key to increased social status, gaining admission to prestigious fraternities and assisting one's future catcer. Peter would nore later that Footboll had opened doors to him and had given him a plate in the life of the aniversity he could never have achieved without it.. The Inter-Fratemity Council forbacc offering themberships until enough time had passed to let prosperts and houses get to ksow cach other and so avoid mismatches. The fratetnitles got around this by telling their facourite prospects beforehand that they would be bid. Choice could be ireacherous; it was imponant to lesm as much aboul one's potential fraternity brothers as possible: 

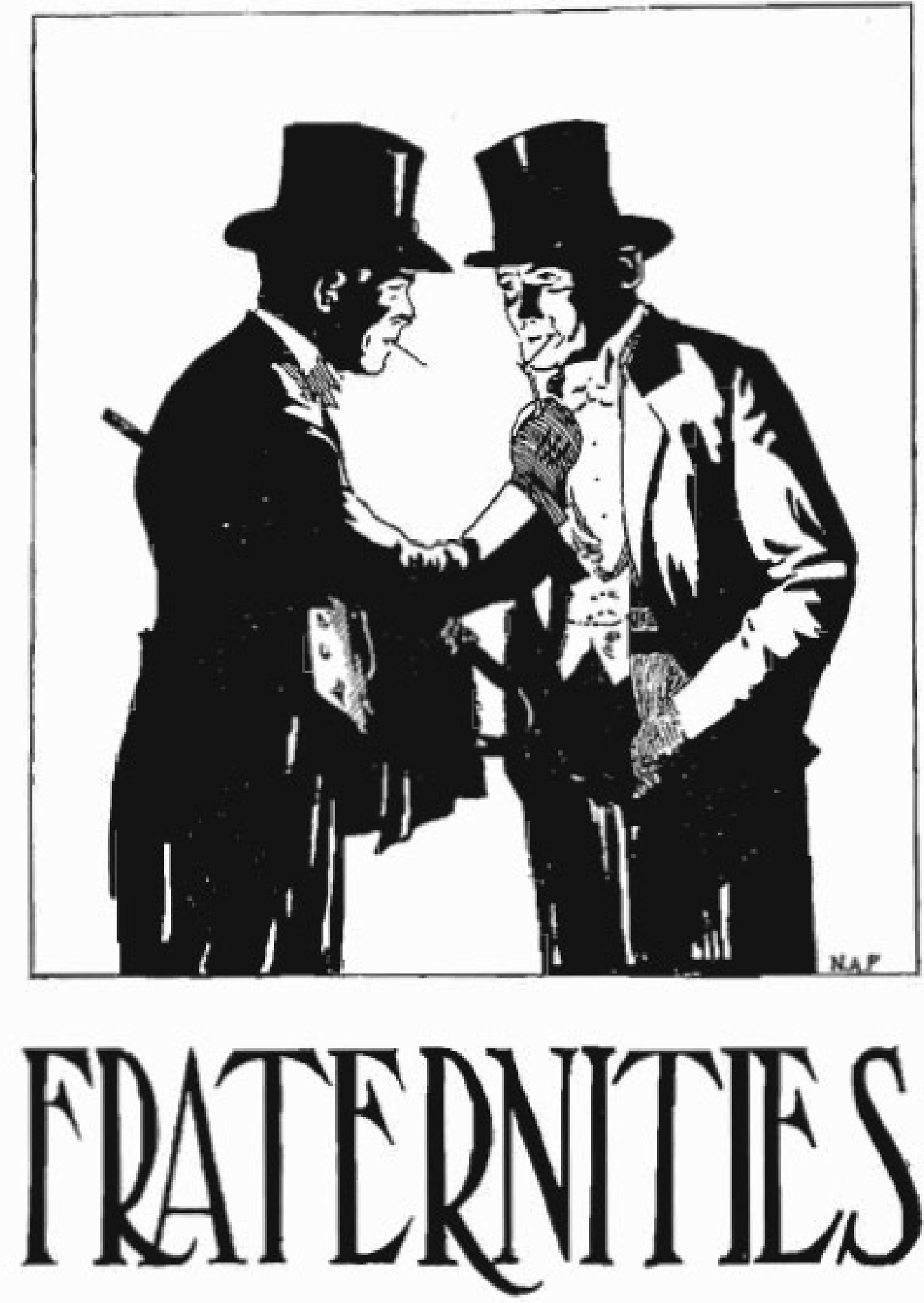

Figure 7. Every fraternity had a legendary reputation. Drawing by N.A. Fellower, Arch. 1927. 


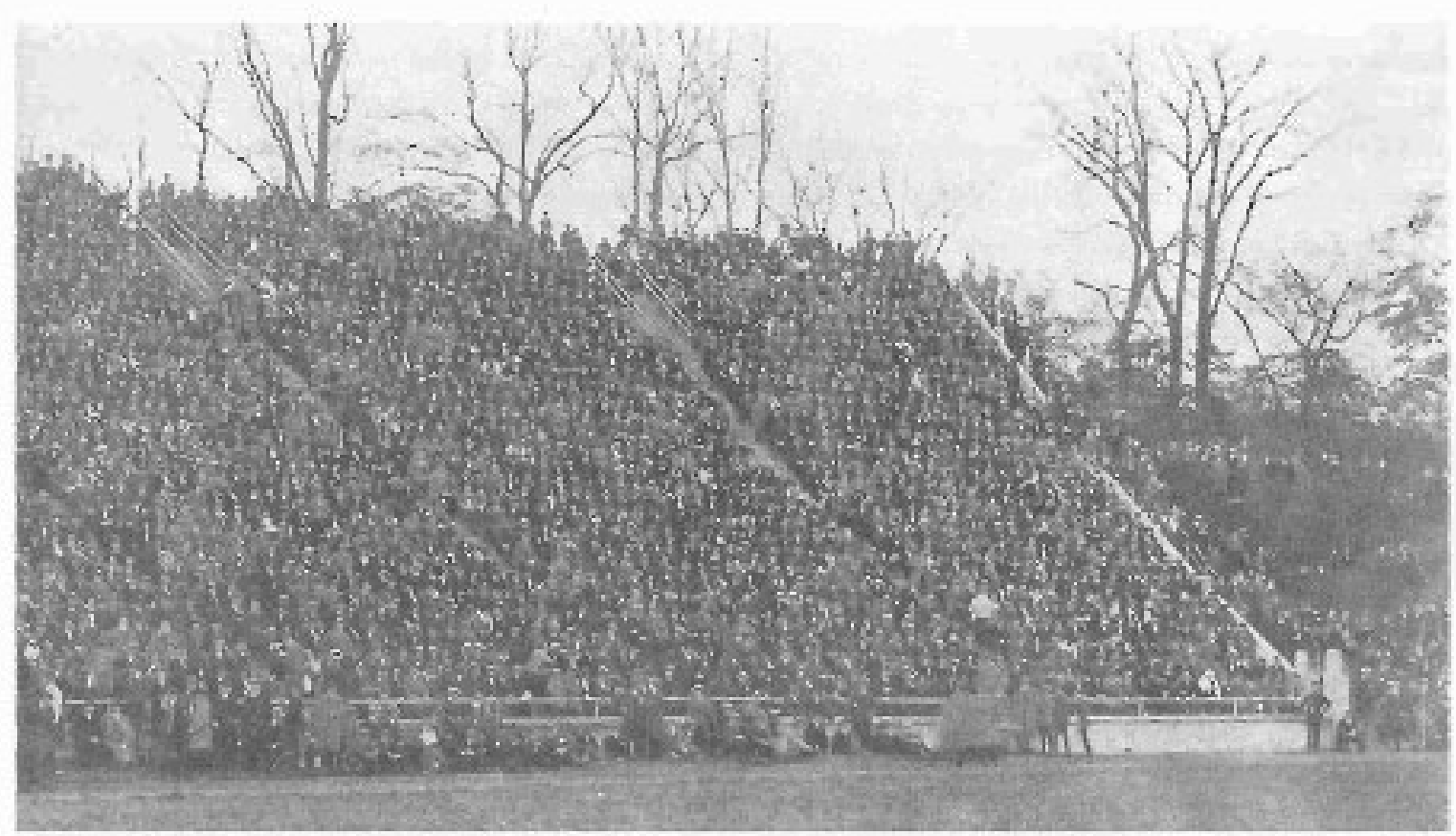

Figure 8. Spectators at football match, Molson Stadium, ca. 1921.

Every fratemity had a legendary reputation (Fig. 7), partly fowided tupon truth, but in most instances the result of the exaggeration of a quafity into a fandt by rival frater. nitits. Thus ons fraternity was a house of unobs; anotiter a house of grinds; another a crowd of alicinolics; wnother wi organixation of thick-skinned athletes; and still another a club for rich men's sons. (p. 14)

In late Octobet, the frateinities make their bids. They compete sharply for the desirable srudents, often helped by graduate members as advocates. One graduate tells Peter that the choice of a fraternity wotid be more important than the choice of a protesslon, religion, business partmet or wite. The firal weck of rusting is tense. Amusing stories circulate. One populai frealiman was diaing at one house but was supposed 10 go to a show right after with another crowd. The first fraternity set the clock back an hour; the student missed his appointment; and the second crowd, which he bad preferred, soured on him. Perer accepis the Rho Delta bid; their frlend. liness seems more sincere than most. Peter hears how the prospects are discussed:
During the next fow days he saw mon he considened decent fellows 'pthled' (blackbailed] because they' 'couldo't hold their Higuor, 'because tincir 'fother was in bade, because they dian'? 'Arexs fike gentlemen,' because thetr Irovher had a bon war record, and for percona! vagaries and antipathies explicable anly to frest ant the brothers who cast the pilis. (p.30)

One prospect is turned down after his Rho Deita uncle has argued in his favour and pointed out he would be tich someday - this is a traternity not a banker's trust, replies a member and the prospect is unanimously black-bailed, as members upinold their gentlemanly indifference to money and their priw. ilege to refuse membership on any grounds they chose, down to the colout of the candidate's sochs.

Carcoll invented "Rbo Deila." He had joined Zeta Psi, a prestigious bouse with chapters at important American universities. The McGill chapter. founded in 1883 , was McGul's first fraternity, At first, McGIII administrators and many students opposed fraternities as secrer societles. In vain: they were firmly established by the 1920 s. The Zetes had many distin- 
guished members in Toronto or McGill, including John McCrae and Stephen Leacock as well as Percival Molson, who had endowed the football stadium in which Peter [and Carroll] played (Fig. 8). Drawing many of their members from the medical faculty, the Zetes had staffed the McGill Hospital in World War One. After occupying other quarters, Zeta Psi built an elegant house on University Street in 1925. In Peter's time, McGill still lacked men's' residences, and fraternities offered members an attractive, prestigious alternative to rooming houses. ${ }^{9}$

Fraternity initiations are secret but similar. Peter must wait on a street corner in old clothes with two dollars in his pocket. He is picked up by a horse cab. Two men, hats down over their eyes, blindfold him. He ends up on Mount Royal, is told to climb a tree, realizes his captors are drunk, is told to jump off the edge of something (still blindfolded) and does. Though it is only a foot drop, Peter worries that they may bung him up for football. Now they ride a while; he feels sure he's in the country. A rope around his waist pulls him off his feet. He is put in a bed and realizes he's probably in the fraternity house. In the next part of the ritua', he hears himself on trial with his candidacy about to fail. Then his friends speak up for him, the blindfold is removed and he is surrounded by his new brothers. In the concluding part of the ceremony, Peter learns the secret hand grip, is told the secrets of the society and declared a full-fledged member. His two dollars is missing - it paid the cab (pp.31-35).

Out-of-towners are expected to live in the fraternity and Peter moves in. He shares a double room with Eric Mowat, an Englishman. Eric finds Canada disap- pointing; there are no cowboys and Indians as the cinema and Canadian Pacific Railway posters had led him to expect. He asks Peter where are the Indians? On reservations mostly. Where are the cowboys? Well, there are some in Alberta. Is that far? About 72 hours by train. For his part, Peter is amazed at Eric's gear: clothes for every possible climate, pictures, tobacco jars and pipes, teapots and books. Peter blames motion pictures and the C.P.R. publicity for distorting Canada's image for people like Eric:

They gave people on the other side a wrong idea of this country. Peter gradually came to understand that he [Eric] had looked forward to Canada as a great adventure, though it was hard to conceive how the product of an English public school could be so misinformed; probably because pictorial art registered more graphically on the mind than the printed or spoken word. He had expected a life like the romantic one depicted in the films of the old west, which had a great vogue abroad. Bucking broncos, cowboys in chaps, six shooters, picturesque and cunning Redskins, hellish saloons and dog teams on Main Street - all the props of the pioneer west - had filled his imagination for weeks. Instead he had found Montreal, which was just another large city, smaller and less amusing than his own London and the Paris he had frequently visited. (p.37)

Meanwhile, the football team nears the end of the season undefeated. Connelly's solid basic training succeeded. The team needed no more than a dozen plays. When plays failed, it was generally because the opponent had a defence for them. To counteract this, Connelly had reverses for all his plays.

\footnotetext{
9 The spectacular new McGill chapter house of Zeta Psi was built as a memorial to its war dead - the first building in Canada designed to be a fraternity house and valued at $\$ 80,000$. It opened in 1925 after Carroll graduated. Previously Zeta Psi occupied a rented house on University Street (No. 635 in the old numbering system) and, in the closing years of World War I, a house at 297 Prince Arthur Street. The latter may be the house Carroll knew. See Howard Bement and Douglas Bement, The Story of Zeta Psi, (New York: Zeta Psi Fraternity, 1928), 168-74, 469-82. In the 1920s, McGill had about 14 fraternities. The history of fraternities at McGill is an untapped source for student history. The archives of individual fraternity chapters are usually held by the local chapters or the national headquarters. However, the McCill University Archives holds some documentation in the records of the Principal and other offices dealing with students or real estate. Entries for each McGill fraternity, listing its branches at other universities, appeared in the annual Old MCGill.
} 
If the straight plays dithit work, then the renerses would, because it was physicully irapossible for a mun to bo in more than one place at the same time. Whan the opposing team shifled its deferce to stop the reverses, then straight power playss were effective... A season of football whder Connelly was like any other couses in the cumiculum. You leamed first principles and were tangh how to apply them. Connelly was learned in his subject, wess conscientious, knew how to impart his knowled and his salary was on a parity with that of most of the' professors. Under his tatelage, a game that had been lurgely

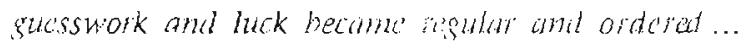
attendance at practice was mese obligutory than allen-

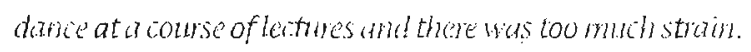
[Peter] had no control whatever over his imatisution.. be forgot that football was primarily fun and recreation. It took on a seriousness on of all proportion to its imporlance. The thing to do was to win. The thinges that he might do which would bring about a defeat were al ways present in his mind... By friklay night he could think of rothing else. He brame grave-faced and detached, paralysed with noners exciternent, waiting for the whisthe and the first fierce contact that would snap the aw ful tensiom. (pp.37-38)

Herc, Peter seems to admit that Mc Gill let sports be over emphasized to the neglect of studies. He wishes that instead of suffering pre-game jitters he could stay cool the way Don Horwill always did. Don was the season's sensation... it was uncamy the waty he could slice through a line, needle-thread his way through the secondaries and find the open field like a crazy colt (p.30)

The season is ending and McGill's tcam must conquer one last opponent: The final game was played against the traditional enemy, Toronto University, from two o'clock of a cold November day until after the sulky' sun went down behind the mountain and the long shadows of the stands and the flagpole dissolved in the wilight blur. The weather was snappy and the big, prosperous-looking crowd, bundled in expensive furs, beat out a rhythmic tattoo with tapping feet and slapping hands. (p.42)
Xeither team scores in Whe first half, lut scontfully tenouncet at half time by Conmelly, the McGill players win the game and the intercollcgiale championship. The seasonends in glory. Carroll rotes that this would be Peter's only championship team. (In reality, McCill won the championship Yates Cup in 19) 19 and aggain in :2928-perhaps Peter is meant to have played in the 1928 sedson. $) \wedge$ celchration dinner at the Wincisor yotel is attended by the "rincipal [Sir Arthur Curric, not characterized. Ilcavy drinking follows; every second marl seemedi to h lave brought a bottle of whisky, (uebec, it will be semenbered, was spared Prohibition, still in force in the States. Tonsts are givent. Connelyy gixes a modest, emotional spcech and is pelted with bread rolls, butter pats, and celery sticks in rerenge for all his sentences of extra lapsancivarbal encouragement. Whorn the Principal andider men leave, the party cuts loose. lhey sing "Alouelte". For the first time Petcr is tight. I c leaves with teammate, Ton Horwill; they go on to crash a supper dance at the Ritz-Carleton Flotel. Peter wakes up the next day at the fraternity, with a headache and his dinner clothes flung all over. He recalls sitting down at a strange table at the Ritz-Carleton and talking to a girl called Anne Somers, engaged to someone dse, one of the prettiest girls he has ever scer. He vaguely remembers talking to her long and eamestly, although he can't remember what it was about. He suspects he has made a fool of himself, but his friend Don reassures him that he has not. Indecd, slie has told Don to bring Peter around sometime. (pp.44-45)

All Fall, Peter had been obsessed with football. As the season conds, the story's focus changes. He notices the rest of the University: both the range of its leaming and the students' casual approach to lectures:

At luncheon at the house, or over the bridge table, you heard a little of everything: the exact amount of tension on the cables of a famous suspension bridge; how much it was going to cost to operate the governmont this year... 


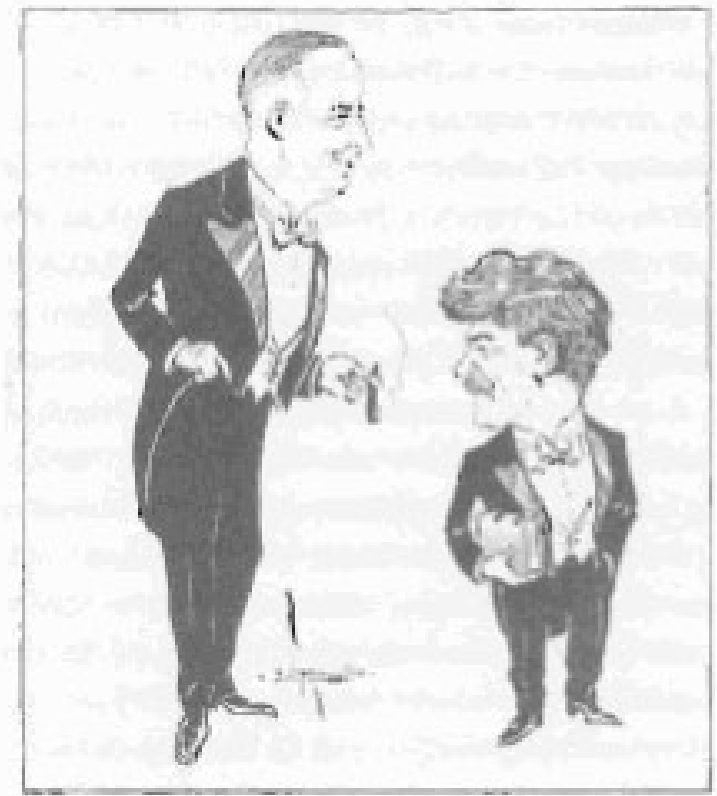

Figure 9.

The profesiors were sympathetic and approachable...

Principal Sir Arthur Currie and Stephen Leacock.

Cartoon by FS. Lemessurtiet, 1923.

the current make-uep of the Reichstag... what was wrong akaret the anchitecture of the Royal Rank Badilfing.... a worid of ideas, stimulating enough, and everyone had the right tospeak or listen, as he chose. The satse of absolute freedoin, of complett indepondence, was new and thrilling. If you chose to slexp in rather that tum up at a lechure, that was your own lookout. You were presimitd to have enough sense to feel responsible, Students canne to iecturn and acted as they pleased. Brazenly they went to stetp right under the Incturer's nose, if they feit he was being dull and they could offord to miss what wos being said. Or they heckled him with absird questions, or stalked out while the lecture was srill in progress. It was goodnatued protest and accepted in that spirit. (pp. 39-40)
In condrast to students at many American universities, McGlll students could cut classes and make their own boarding amangements. In 1925 Principal Currte's assistant asserted that in Canada "the general policy has always been to interiere as litule as possible with the undergaduate. 10 The professor weresympatheric and approachable and often drank with students in tavems; no subject was taboo (Fig 9). Peter notices that McGIll students atgue excitedly about every subject on the curriculum - history, economics, and psychology, with an intensity he had reserved for football.

Peter discovers that, unlike some other universities, McGll1 does not tum out a sundard, identiflable product: The saniversity did not produce any specific type, perhaps because is student bodly wus so cosmopolitum and exposed to too many influences to allow any one to predominate (p.40). (In Peter's day, sbout 1927. there wete 2772 students at McGill, including 1038 in Auts, 757 women, 229 Americans, 59 Englishmen and one Englishwoman.) A student's expenses for an scademic year - tuition fees, lodging, board and books - were estimated to cost about 5900 . "Rather than lake on a standard veneer, studen's tended to keep theit original identities:

The Medical Faculty, wid/ Sir Willian Oslat its prize prod. uct and still animated by his ideals, was famous all over America. The faculty of Sciense was not far behind. These two schools atbrasted students from everywhere, who matrakged to kecp their idenaty? Bare-headed Englichmen, in favanel bags and sports conts, roamed the campus ino matter what the constition of the weather. In the halls. one suw American youths in polo shirts and cres sovetaters, Acard American accents varying all the way from New Eveland to California. There was a hiberal sprinkling of West hadians, laoking tike Negroes and employing the voices of Old Country Englishmen. In Peter's foculty there

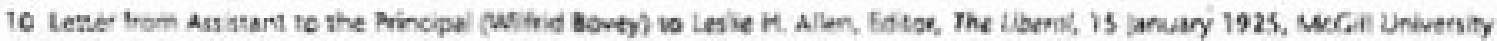
Archives, Principars Otfice, \&C 2, C 46, fie 4\$9, L- Ik 1921-1934.

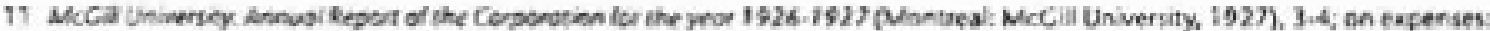

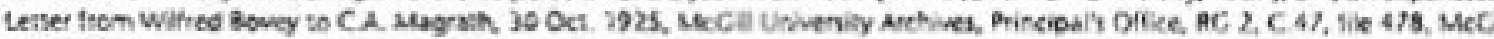
$2922-1939$. 


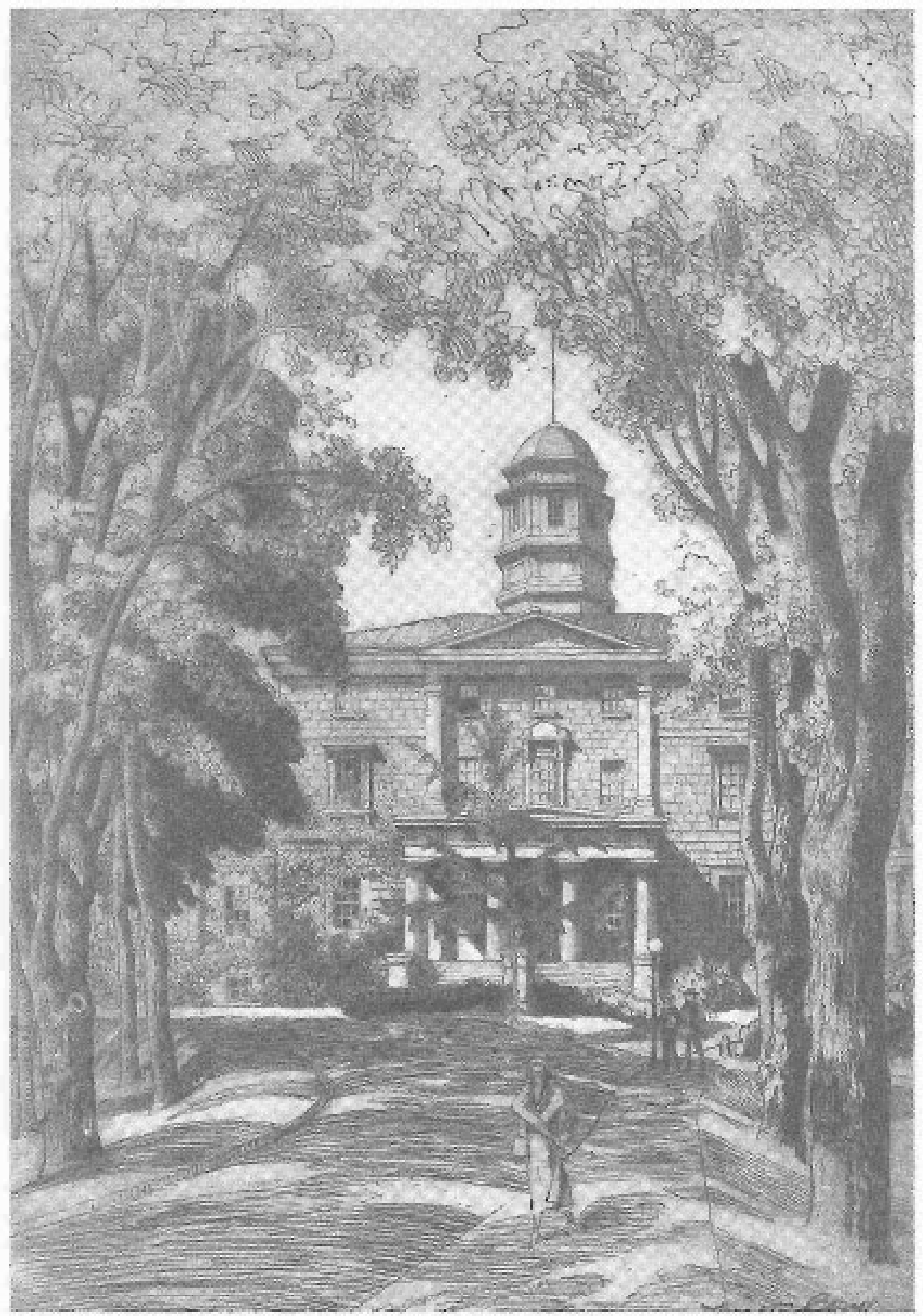

Figure 10. The Arts Building nefurbished a number of times, was the original building of the Untiversity. Drawing by Walter R. Dutf, 1924. 
wats a gowuine Chinese prince. But by far the bulk of the student borty consisted of Canadian born lads from every province in the Dominion. There were many FrenchCanadians, and Peter found their odllly accented manner of speaking extromely droll, though the fact remained that thry could all speat Eiglish and only a small percent. age of the English bom population could speak French. It gave him an odd sensation to hear the moll called. Lachance, Lafewr, Lafontaine, Laliberte, Lamont, Lemolne. Examination papers could be wrinten in French or English. He began to develop an ear for French and he thought he could distinguish those who had studied abroad, as many of die French-Canadian students had. (pp. 40-41)

Peter looks at the campus atchirecture, the stately old buildings facing Sherbrooke Street, Moniseais equivalent of New York's Fifth Awenue, and notes that McGill was built not by government but by private benefactors:

The university had celebroted its centermial amniversary six or seven years before lin 1921], and the Arts Building, refiubished a mumber of zimes, was the original building of the saniversity (Fig. 10). Long and low and darkened by more than a century's dist, it stood ot the very end of the driveway ohat lead up from the gates. Mare tire rical split, the two now sections carving awny on cither side. To the right of the main mad were the science buildinss, of a newer vintage, the contrithution of a grat tobacie fortume [Sir William Macdonald's]. To the left were the moss-covered library... and the Musaram, whose donor [Peter Redpath) had made millions in sagar, The Medical buildings [gift of Losd Strathcona], mewer still, wire in back of the Arts Building ferther tap the hill and closer to the Royal Victoria Hospital (Fig. I1). The city's capitolists had given both money and affection in large gabs to the smiversity. (p.41)

Novels and memoirs referring to McGill often focus on the campus's archirecture: the horseshoe of greystone buildings, in a hodgepodge of deconted nineteenth-century styles; facing the mansion- lined boulevard of Sherbrcoke Street; and its imposing gates and elm-treed road. At the road's end is the weathered greystone icon, the original Arts Building, dating from the $1840 \mathrm{~s}$, long before the little college was tuansformed by Dawson, Oslet, and Rutherford into Canada's national universiry, renowned for medicine and science. And always looming above is Mount Royal. Writers focus on the tall ancient trees and odd gtey buildings. Carrolits friend Hugh Maclennan wrote about McGill's campus poetically in The Watch That Ends the Night (1959), as did Hatold Trott in his memoir. Carroll described its atmosphere in the 1920s:

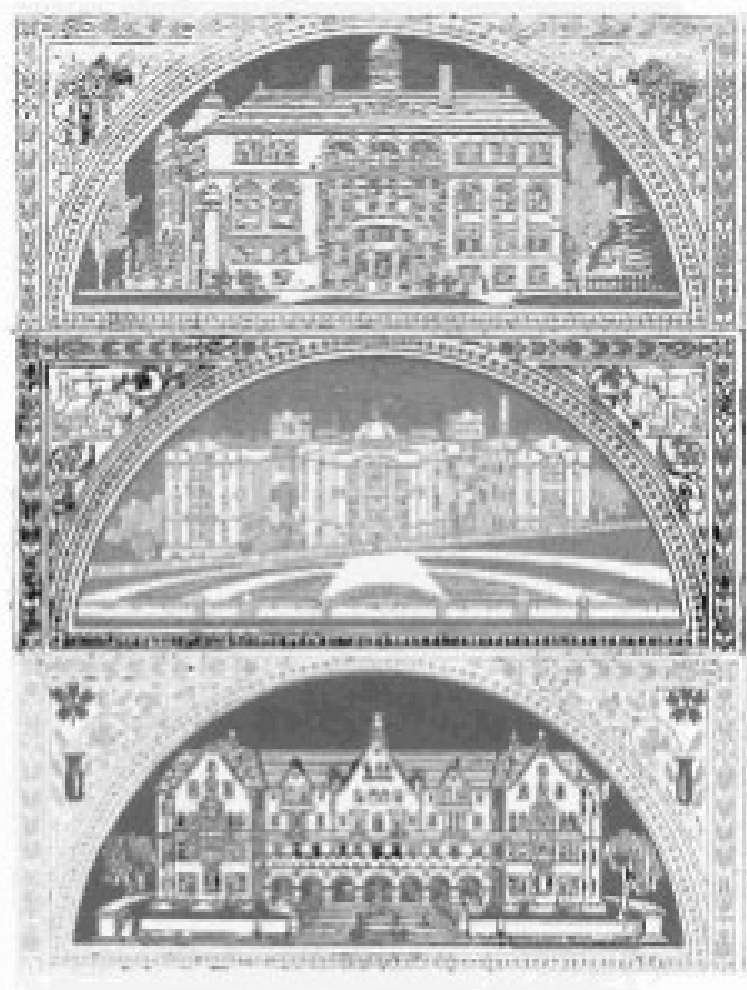

Figure 11.

The dity's capitalists had given both money and affection in large gobs to the university.

(The Macdonald Physics Building. the Strathcona Medical Building. and Royal Victoria College.) 
The campus, fringed with giant elms, was a magnet for old and young. White-flannelled cricketers set up their wickets on its green turf. Tennis players dashed about its red clay courts. Bearded old men walked reflectively under its trees and children, under the watch ful eyes of governesses, played albout on its grassy slopes. Late at night, undergraluate revellers lurched along its narrow sidewalks. (pp. 41-42)

With football over, Peter becomes an ordinary mortal. During football season, the fraternity had excused him from the duties new members, known as "babies," carried out in the house. They had to answer the doorbell and the telephone, keep the common room tidy, prepare the chapter room for meetings, mail letters to the alumni, and do odd jobs. Peter and his roommate Eric resent the chores and are censured for their apathetic attitudes at house meetings, not realizing such criticism was routine and not meant personally. Eric complains, When I was first introduced here I was given the impression that it was a gentleman's club... Then after one is persuded to join, one is treated like a steward (pp.45-46). When Fric talks this way, Peter thinks of the pompous stage Englishman. Yet he enjoys Eric's mannerisms:

Eric had so much more dignity than Canadian youths of his age that it sometimes appealed to him as ridiculous. He was, in appearance, the clean-looking type of English public school boy you see in the illustrated London papers. He looked tall because he was slender and long in the legs, but in reality he was only a fraction of an inch taller than Peter. He had a long, thin English head and narrow face, skin like a girl, pleasant blue eyes and hair the colour and quality of corn silk. (p.46)

Eventually Peter and Eric get into trouble. Assigned to polish the common room floor, they begin after breakfast, when the house is empty except for the servants. Soon Eric suggests they hire someone to do it. So a derelict from an employment agency finishes the job for them. Unfortunately the house president, Ken Hyde, returns and sees what has happened. At the next Saturday meeting, Hyde announces that two of the new brothers have refused to perform a menial task assigned to them and will be disciplined after the meeting. The whole chapter seems to know about it and two brothers are sent to prepare the freezing mixture.

When the meeting adjourned, they wercescorted upstuirs, stripped of their clothes and conducted to the bathroom. Then they saw the freezing mixture: snow and ice and salt and water filled the tub. The bathroom and the hall outside were jammed with grinning brothers, eager spectators at the first bath party of the year. Eric was grabbed by the feet and the hands and hoisted into the air. () nce, twice, three times they dipped him in the icy tub and, each time as he was lowered, a mock cheer rent the air. A bath towel was flung over his shivering shoulders and he was led awery, while Peter was subjected to the same treatment. (pp.47-48)

Afterwards, Don Horwill says not to take it too seriously. It happens to someone every year, means nothing, and is good for discipline. Eric feels insulted and thinks of resigning his membership. However, he is persuaded that if they do not laugh it off, their lives might be made unpleasant - each assigned chore could provoke a crisis. Resigning could spoil one's university career; the individual not the fraternity would be blamed. Peter notices more things he does not like. Ireshmen are discouraged from full participation in house politics. Another "baby," 'Tim Manson, who had grown up on ail Alberta cattle ranch and who was taken in only because his brother had belonged, naively suggests at a meeting that the fraternity reform its treatment of new members. After an ominous silence, the president declared that the traditions of the chapter had stood for nearly fifty years, and it was presumptuous of a "baby" to criticize - so presumptuous that Tim is subjected to the same freezing immersion meted out to Peter and Eric. Peter begins to find the fraternity too like an army barracks. Ife is also disconcerted that his brothers 
ridicule the dances and potential romances that are part of life at co-ed campuses like McGill's by the 1920s.

\section{WINTER: BOOKS AND BEER}

The term has ended. It is January and exams loom. Peter had brought notes and books home to Ontario to study over the Christmas vacation. But he had goofed off, gone to parties, and basked in the admiration of local girls impressed by his football feats. Back at McGill, he realizes he knows nothing about the four Arts subjects he's taking - He had neglected the primary, academic side of college for football and fraternity activities (p.51). We hear nothing about Peter's courses. Carroll like most college novel writers, concentrated on sports and extra-curricular socializing. As everyone crams for exams, the fraternity house becomes quiet: the threat of examinations muzzled the radio and the victrola, dimmed bright lights into student lamps, gagged the garrulous and drove the bridge players away from the tables (p.51).

Peter now pays the price for exercising his freedom to cut classes. He makes a last-ditch attempt to catch up on his studies, living on sandwiches from a restaurant, coffee and caffeine tablets. When the results of the January exams are posted, he finds he has failed two courses. His prestige in the fraternity drops, since failures lower the chapter's status on campus. The fraternity president starts to keep an eye on him. Then he hears Coach Connelly is off him: He says you're the kind of guy who makes all that overemphasis talk possible (p.53). Throughout the 1920s, the professionalization of college sports caused controversy. Indeed, the 1928 Old McGill carried an article, "The Over-Emphasis of Athletics," warning that Canadian universities were in danger of falling into the American practices of dropping academic standards, commercializing sports, and even paying players. ${ }^{12}$
To recoup academically, on Don's advice, Peter prescribes a new routine for himself. He finds he can attend his lectures, spend two hours in the library and still have free time (Fig 12). Football seems long past, as Peter's interests turn more cerebral. He discovers a passion for books and ideas; indeed his reading of novels appears to be his private alternative to McGill's formal curriculum. After lectures, he starts going to the Student Union where he meets students talking from table to table about literature, theatre, campus affairs, and Professor Leacock's latest bon mot (p.55)

'Have you heard Stevie's latest?' someone cried with a burst of preliminary laughter.

'Let's have it.'

'He says O. Henry is the great master of modem literature.' 'No! Did he mean it?'

'Who can tell?'

'He's probably just living up to his reputation as a funny man.'

Peter learns that because students in Arts and Law have easy courses, they can drop into the Union cafeteria for both morning and aftemoon sessions, over tea, coffee and pipes - students never seemed to be able to talk without eating or drinking at the same time (p.55). Peter discovers the "Aesthetes" - the theatre and literary crowd. They know about literature and drama, even music and painting, and argue hotly over the latest play by O'Neill. Some write for the Mo :ill Daily or for the "Literary Review." Those too superior to write talk. Carroll probably modelled the Aesthetes on the students who wrote for the McGill Daily Literary Supplement in the early 1920s, and more particularly for the McGill Fortnightly Review, which came out to acclaim from 1925 to 1927. Known as the "McGill Group" or "Montreal Group", the students included F.R. Scott, A.J.M. Smith, Teon Iidel, Eeo Kenneciy, anc: A.M. Klein. Many of the McGill group went on to distinguished Iiterary careers. At MicGill they 
cspousci modernist poetry, admirec klicot and Yeats. and reviled the lingering Victorianism of Carradiarn letters. del recalled that the Mc(iil Fortrigently grow: would talk :n the MoGirll linion with others of similar intercsts like Graeme: Taylor and Jolm Glassco. Linlike the other Wcri:? writcrs, Glassco would a'so writc crotica of the governess genre. ${ }^{1.3}$

l'cter $\cdots$...cets Tony Dodids, a frier:d of the Aestinetes. Tony plays the jiano in the linion, writes mus for the student Red and write Revue, and :) lays the ader guicle to the natve peter. One afternoon, l'eter anc: Fony desct the hinion for the stucent ralut, the Prince of Wa es lavern, known as th: "s: gar. Whiste, on Mce: ll College Avenue. This (real-life) tavern played a large part in studer: :ife for decades. For Mcrill studen:s:

When you suiu ber, yon meant the l'g.... The Pio :las smoky, noisy and cheerful. l'eter and "ory sit dows: ir one of the cubices hat ires the wat. Turo men iworked fow rishly behind the counter supplying the weit as with hottles of ule, drerving steins of thaft beer and reidying food orders to the kitchers... When they weren't

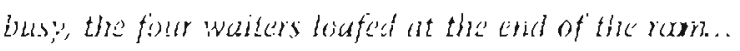
sullowing occosional becrs with prodigiens spoed. The were extremely gowel nuturel, tock a lot of kidding,

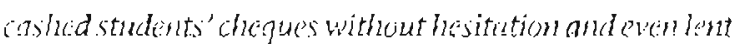
them inonoy. "ihy' were all Fiench Canudiais: Armond, fat ard jolly; Alyert, thins, short and bespectucled Rig Rumeco, us lank?;, loos-jointed and soft-spoken as a Newro;

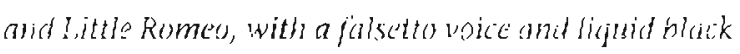
(yyes a.s soff as a wisnan's. (p.S\%)

The boys ower two Wo sone, which the waiter Armand calls "molesizins," an linsiring joke. Aftera few drixlirs, l'eter eecls 'ike skippirg rlipper at the sate: rity: le had a feeling he wanted to de something t( -nishi, have a little excitement, sec alittle iffe (p). 58-59), zter and Tony mesve on from the Pig to Kralismar.'s ir.

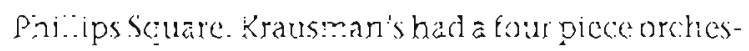
tha which played viennese waltzes. 1: had ost its onlarity becausc of the War, but it still served exce:lent locks and isaut anc lisner beer. "Tony asks Peter how ha" ]:kes the Aesthetes. Peter says ine "ikes lis:ening to them. When Tony grirs slyly, ?eter adds,

On, I krliw what they' say about them,.. but you cun't believe that stuff. Tory broke into u inugh. latin't know... A couple of those shys losk a little delicate to me. I wildn't like to go on any long anot trips. with them.' For al fleoting moment, feter wes wary; then ho almost laughed out loud at the absurdity of his suspicions. Why

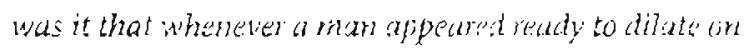

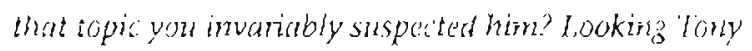
over, he decided that he certainly dith't display any of the badpes of the order. There wes ne precicisity in his

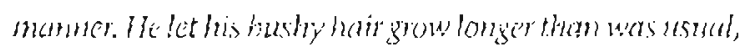

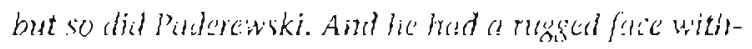
out a tracen of ferminimity in it. For the rest, his wit wes.

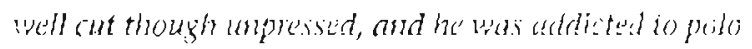
shirts with soft confortable collars, The :nscmble was carcless, but it had a chality of deliberetencess chlolet it partomuble in aysulth with a facile talent for musical composition. (p.60)

Charging the subject from the love that knew no name, cspecially at lic:(ii!, they talk about the goal of ecucation. We are tokit's not to each is to maxe a livirg, but to make lis cultured, says lor:y. Thinen tile education system fails, declares ?eter. I:

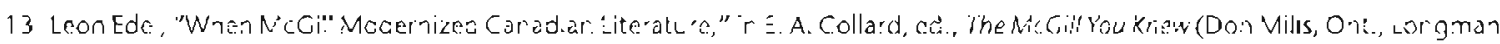

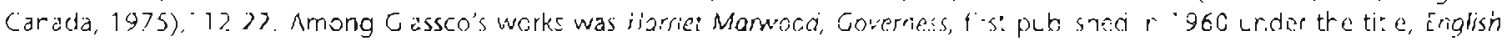
Goversess.

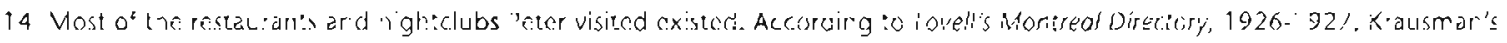

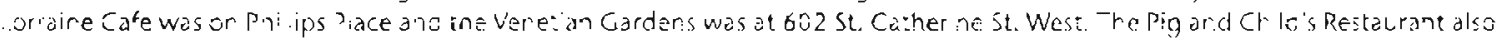

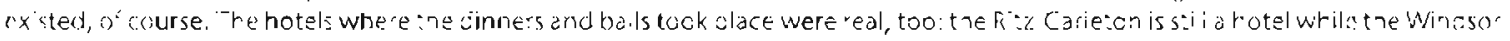

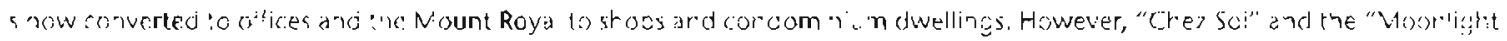

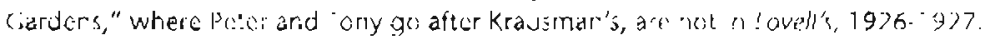




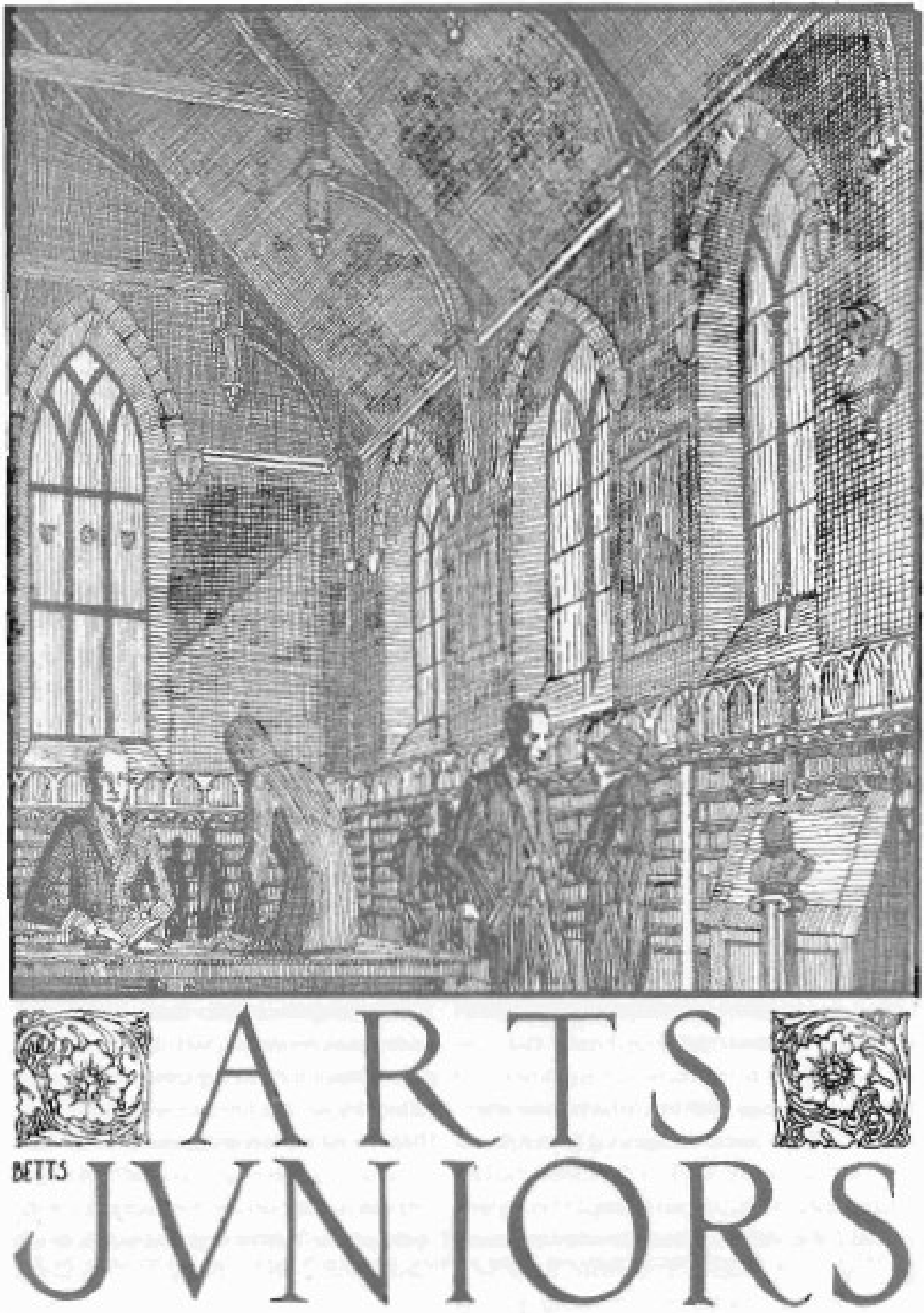

Figure 12. Peter spends two hours a day in the (Redpath) Libraty. Drawing by R.C. Bets, Arch. 1928. 
criticizes McGill for its lack of courses in the arts, music, and painting. He knows nothing about painting or any of the arts; he has a sketchy idea of literature only because he was curious: Why couldn't they give us the rudiments?... enough to stimulate our interest. They manage to in European schools (pp. 6061). Contemporary critics shared Peter's frustration that Canadian Universities falled to instil culture in their students. In 1930 A.F.B. Clark singled out McGill and Toronto when decrying sterile literary scholarship for concentrating on dry philology instead of great ideas. ${ }^{15}$ Playing devil's advocate, Tony argues that history is made by warriors and statesmen. But they don't teach us anything, says Peter. They mix their conversation with lots of Pilsner. Tony spouts about the lives and loves of famous composers: Dvorak's drunkenness, the evidences of homosexuality in Wagner's work... the Vienne of Franz Schubert and Richard Strauss (p.61). Tony wants to visit Austria and Germany, where good food and good music come first; and the women over there, he was sure, even the professionals, were more sympathetic and less mercenary than the bags in this mar's town, with whom he was entirely fed up (p.61).

By three in the morning, they find themselves in Chez. Soi via the Moonlight Gardens, in the east, French-speaking part of town, exotic to Englishspeaking Montrealers:

far past the boundary line fixed by nice people as the farthest you could go in an casterly direction after nightfall. The women were obvious enough: different versions of the sarne type. The men were more heterogeneous: people employed in the amusement business - jazz band players, vaudevillians and waiters - who came down here for relaxation after their own establishments closed; respectable business men, a little the worse for liquor, making a night of it; one or two undergraduates like thenselves thinking they were exploring the depths; and the usual number of touts and pimps ifudigenous to the place. (p.62)

Peter tells Tong he is curious to see "a house. "Until civic reforms in the 1950s, brothels were kept fairly openiy in some seedy downtown districts and, according to fiction and memoirs, sometimes were visited by the more venturesome students. Actor Hume Cronyn recalled that when he was a McGill student in 1931 he frequented Flo's on Milton Street and caught the clap. " Tony knowrs where the houses are, in spite of the efforts to eradicate them by the "Commitfee of Sixteen" (a Montreal reform group active around 1920). He takes Peter uptown to a row of ancient, red brick, two-story houses. A panel in a door is slid back. They are admitted to a front room. The madame has a heavy accent, tawny, wine. coloured skin, and something of a moustache. She reminded Peter of the madames of stage and fiction. The madame rings a bell for the girls. While they wait, Tony puts a nickel in the piano slot; it plays like breakirig glass. (p.6.3)

Peter wasn't prepared' for the ghastly half-dozen 'girls' who filed into the room in various stages of dishabille... They were grotesque - caricatures of women. Their makeup was as thick as a circus-clown's and, when they smiled, they showed hideous zold teeth. He stared at them for a moment, foscinated. From the depths of his chair, Tony laughed. The madame looked from one to the other of them with concern. 'Come on, 'she urged, 'choose your girl.' Tony laughed still harder. Peter leaped nervously to his feet. He wanted to get out of the place - at once! If he stayed there another minute he would be contaminated... (pp. 63-64)

The boys leave. Amused, Tony says that it is the worst place in the city; he just took Peter there for

15 A.F. B. Clark, "Literary Scholarship in Canadian Universitles," The Canadion forum 10, no. 115 (April 1930): 24A.48. In similar vein: H. Steinhouer, "Why We Have No Creat Canadian Scholars," The Canodion forum 10, no. 117 June 1930): 321-23.

16 Hume Cronyn, A Terrible Liar: A Memoir, (Toronto: Key Porter Books, Toronto, 1991), 81-83. 
a lark. Peter retorts that it was awful: Those women weren't human - they were like ghosts... How could anybody ever have anything to do with them? (p.64). Tony replies that the customers are sailors or longshoremen, not very particular. He assures Peter most houses are better; this is the worst. ${ }^{17}$ Home in bed, Peter imagines those painted faces grinning at him. Writers of the time often portrayed prostitutes as garishly made up, disease ridden and aging. The clients seem to be re-enacting their older brothers' harrowing war experiences - they go over the top to face, not German guns, but venereal disease and police raids. Pleasure is ali but forgotten.

After this misadventure, Perer happily returns his attention to the campus, now frozen in Montreal's winter, unforgettable for students from gentler climates:

Winter laid deternined siege to the land, sending icy blasts rouring down out of the northwest in consecutive waves (Fig. 13). Layer after layer of snow brilliantly redecurated the old summerhouse in the neighbour's yard and, in the momings, the kitchen maid struggled with the milk bottles, frozen to the doorstep. Goif bags and sweaters disappeared from the cloakroom of the Rho Delt house and skates, skis and windbreakers appeared in their stead.... At night, linder the arc lights, forms moved jerkily, like dancing marionettes, about the campus rinks, and the mountain was black with flying figures in the moonlight, their hazardous flights propelled and guided by a pair of frail poles. The transportation companies advertised special excursion week-end trains up north, and the display windows of the big departmentai stores looked like miniatures of St. Moritz. (p.65)

Peter cares nothing for skiing. He enjoys watching bis English roommate Eric Mowat piling coats high on his bed at night against Montreal's winter. Peter is amazed at how methodically the Englishman sorts his clothes: dress shirts, collars, socks, gloves, pajamas all carefully sorted into separate drawers; formal clothes (which Peter will borrow before the story ends) hung carefuily in a bag. At first, Eric has been disappointed with Canada, but now he begins to study the differences between Canada and the Old Country. He follows professional hockey rabidly, keeping a notebook on Les Canadiens, the Maroons, and other clubs. Eric also studies North American slang: Peter told him that, so far as he knew, it originated with the sports writers, the Broadway stage and the underworid. So Eic reads the sports pages and grades Peter on his knowledge about the gangsters in the beadlines: Where is Cook County? What is a stool? What is a gorilla? Who is the pay-off man for the Capone mob? The "Talkies" come in [ca. 1927] and Eric loves them (pp. 65-67). He sees "Broadway Mejody" seven times, while. American gangster films make up for the Canadian cowboys and Indians he will never see.

Peter pursues his reading and attends a lecture by G.K. Chesterton, in town on a tour of North America: 18

He was disappointed in the enormous man with the long

17 While this house presumably was imaginary, Al Palmer reterred to a real Maggie's far east, on Clark Street, when describing the red-light district in the decades before 1950 in Niontreal Conidentiol, (Toronto: Export Publishing Enterprises, 1950), 12. On the brothel milieu, see also Ronaid s. Cooke's novel set in Montreal in the 1930s, The House en Croig Street (Toronto: Publishing Enterprises Ltd., 1949). The Committee of Sixteen was a private watchdog body, consisting mainly of English speaking Montrealers, including Lady Hingston and ], Howard Falk, Director, Social Service Department, MeCisl Liniversity. The Committee of Sixten cited sociological and moral arguments for suppressing prostitution in Some facts regording tolerotion, regulorion, segregation ond repression of commerciolized vize, Montreal, 1919. Avowing that Montred was a strategic poini in international white slavery, Evanstonl. Hart also advocated teetotalism and denounced Stephen Leacock for defending the freedom to drink; Leacock's attitude (wrote Hart) should deter parents from entrusting their children to McCill: Evanston i. Hart, Wake Uo! Montreols: Commerciolized Vice ond its Contributories (Montreal: the Wilness Press, 1919), 24-25, 32.

18 Carroll himself may have heard Chesterton when he toured North Americ.a, inciuding Montreal, Toronto and Ottawa, in 1921. Chesterton described his impressions, ignoring Canada, in Whot I Sow in America (Landon: Hodder and Stoughton, 1923). 


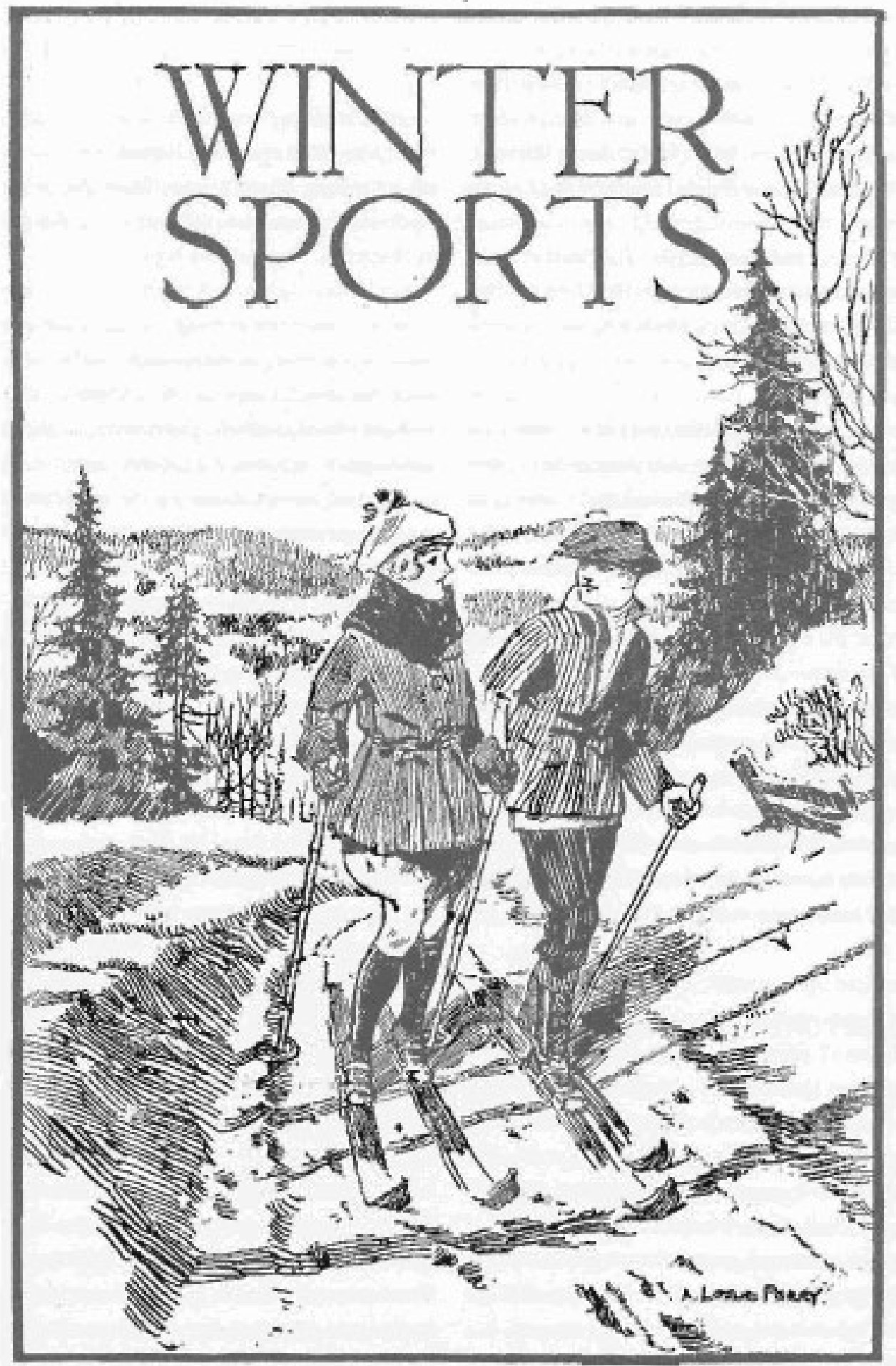

Figure 13. Winter laid determined seige to the land...

The transpartation companies advertized special excursion trains up north. Drawing by A.L. Perry, Arch. 1923. 
hair, baggy clothes, tortoise-shell glasses and lightning repartee possibly because his subject was not one in which he was particularly interested. He would have liked it better if it had been more exclusively literary, though there were many references to Wells, Shaw, Barry, Bennett, Galsworthy, Walpole and Huxley. (pp.67-68)

For a while, Peter switches allegiance from American to British novelists, lured by their greater sophistication and their ancient society, where families had lived on the same land for centuries:

They seemed to know so much more than the American writers he had been reading and to be surer of themselves (with the possible exception of Dreiser). But it was difficult for him to identify himself with their world. He tried to analyse the trouble and came to the conclusion that it was because the families they wrote about had lived a long time in the same place. Their backgrounds were firm, fixed and secure. In Canada, as in the United States, it was unusual to find a family that had lived in the same house for more than one generation. The children grew up, the boys went to the big cities or to another place where business opportunities were better, and the girls married and adopted their husbands'domiciles. There wasn't much in them [British novels] either about the struggle to make a living; their battles were mostly in the mind. (pp.67-68)

\section{SPRING: BEYOND THE GATES}

Winter recedes. Having played football, adapted to his fraternity, drunk tea at the Union and beer at the Pig, and read more novels, Peter further explores the city beyond the campus. Through his fraternity brother and team mate, Don Horwill, Peter meets Neil Richards, visiting from his New England boarding school. P'eter is invited to Neil's family house on Upper Drummond Street. It is another step in his education: how the rich live.

The house was enormous.... Peter was impressed by everything he saw: the rich rugs, the period fumiture, the books in the library, the oil paintings under their individual lights and the quiet efficiency of the servants. (p.70)

Neil looks up to Don as a role model, and tells Peter how Don once had leaped into Lac St-Louis to save a power plant worker from drowning. While Neil talks about Don, Peter, too, muses about Don as the solid, dependable type:

... he was remembering things about Don during the past year: his enthusiasm for football and his utter fearlessness; his concern over his own [Peter's] failure in the mid-term examinations; Don joining in the chorus of a lewd song at the house one Saturday night in such a spirit of fun that the viciousness of the words was somehow neutralized.... the secret of his charm, of course, lay in his abundant good health, his natural optimism and his total lack of affectation.... He doubted if Don had even the average amount of imagination, or if he ever took time for reflection. He was first and foremost a man of action, whereas Peter was not at all sure that he fell even remotely into that classification. (p.71)

Neil is different from both the forthright Don and the cautious Peter. He is more elegant than most Canadians, privately tutored, and reads French novels. His American father had married a French Canadian Montrealer and become a broker in Montreal. Peter is impressed by Neil, the upper class boy, as he had been by Eric's Britishness and Tony's sophistication. Neil regales Peter with his travels: getting tight in Paris when he was fourteen and the like. Peter thinks that Neil's upbringing sounds like something out of a novel. He guesses that Neil is no stranger to sexual adventure: The French all seemed precocious that way, which probably accounted for it since he was French on his mother's side (p.73). (Peter wrongly assumes French Canadian attitudes are the same as those of Paris.) At Neil's house, Peter notices numerous French novels. Peter knew little about French literature but he understood that the French treated sex as of no more importance than food, clothing, or any other feature of day to day 
existence. In that case, early familiarity with it was not so shocking (p.73).

Peter, Neil and Don attend a new McGill tradition, the Red and White Revue. The boys have prepared by having a well-lubricated dinner at the RitzCarleton Hotel. Tony Dodds conducts the overture:

It was medley of many things, half-recognizable suggestions of college airs... Scene followed scene-sketch, chorus, blackout - with bewildering rapidity.... The star comedian that year had genius. He ambled all over the stage, over the footlights, on to the piano and into the body of the theatre, ad-libbing his way with a Broadway virtuosity. The co-eds were comely and the wit plentiful... (Fig. 14). The writers played no favourites: the weaknesses of the Prime Minister at Ottawa, the Mayor of the city, the Principal and the professors were lampooned in satirical sketches; but the satire was kindly and the kidding had a merciful quality. There were occasional bright spots that momentarily stopped the show, as when the Principal, irate, rang for a certain professor, a mathematical wizard with a well-known taste for nut-brown ale, who was momentarily not to be found.

'Find out where he is!' the Principal thundered into the phone. A moment later the instrument tinkled.

'Hello,' he said gruffly.

'Where?' His voice took on a dulcet quality. 'With the Prince of Wales?'

More words on the other end of the wire and the Principal's perceptibly changing expression.

'Oh!' he said frigidly. 'AT the Prince of Wales'. (pp.74-75)

Carroll may have invented this skit, but Principal Sir Arthur Currie and many professors indeed attended McGill Theatre Nights. In March 1923 (Carroll's graduation year), the Montreal Herald reported that the audience, including the Principal and most of the staff, were kept in convulsions of laughter and applauded every act enthusiastically. ${ }^{19}$

After two hours, the Revue winds up with "Hail Alma Mater" and the University cheer. Peter, Don and Neil drive in Neil's Cadillac to the cabaret sequel at the Mount Royal Hotel. To keep damages by unruly students down, it is performed in a lower level room with stucco walls, not in the ballrooms. The crockery is solid here. Even the champagne glasses were durable enough to hold ice-cream sundaes. The crowd swelled rapidly, smoke hovered thickly under the low ceiling and the heavy fragrance of perfume and powder mingled with the scent of tobacco (Fig. 15) [p.76]. People order champagne, others drink from bottles and flasks discreetly hidden under tables. A second bottle of Mumm's is deftly substituted for the empty in the wine-bucket under their table. Girls are at a premium; stags look for vulnerable mixed parties. Between the cabaret pieces, there is dancing:

Suddenly Don, who had been searching the crowd with speculative eyes, bounded precipitately to his feet and bore down on a couple dancing in a corner. The girl was smiling encouragement, unknown to her partner, whose back was to the intruder. The cut-in was accomplished with easy dexterity; her crestfallen ex-partner looked dumbly after them... (p.77)

Don does not return. Neil must go back to Groton soon. He complains that it's no fun without girls and tells Peter they'll go somewhere else. Peter asks where. Neil tells him to get in the car and leave it to him. Peter had had a lot to drink and his judyment had waned with the evening; he goes along. Neil drives south of the Mount Royal Hotel and turns west on Dorchester to a decayed, once elegant neighbourhood, between Guy and Atwater Streets. A few decades previous this had been the most elegant section of the city, before fashion had pushed on seeking the heights lup the Mountain|. Some old families still dwelt in the vicin-

19 The Montreal Herald, 23 March 1923. 


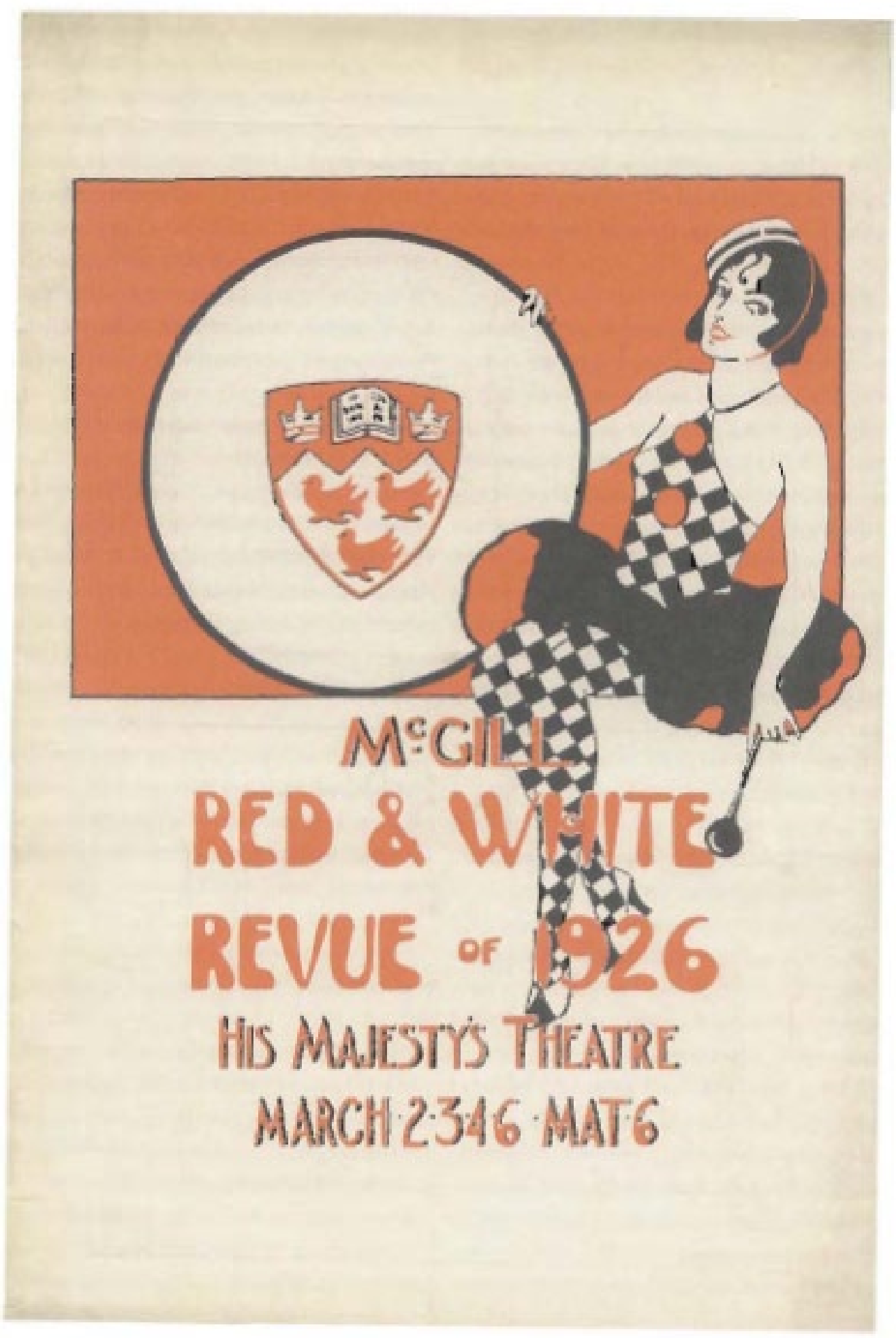

Figute 14. It was a medicy of memy thing..

The co-eds wene comely and dhe wit plendiful 
ity, in those huge, dark houses well back from the street (p.77). [One of them, the Shaughnessy house, would survive to become part of the Canadian Centre for Architecture in 1989]. A row of smaller houses stood nearer the sidewalk and Neil leads them to one with a rounded facade. They knock and Neil flicks his cigarette lighter to show his face. The madam recognizes him, opens the door, and complains he should have telephoned ahead.

She was a rather stout midale-aged woman, with an ugly face and a kitten in her arms. She had a great deal of hair, not too tidily done; but when she smiled her fleshy features were momentarily transformed and you did not think of her as being ugly. Peter was reminded of certain photographs of celebrated French women he had seen: Bernhardt or Colette or somebody. (p.78)

Neil introduces Peter. They order champagne, brought by a maid. The madam leaves to telephone some girls. At this point, Peter realizes he is in a brothel. Before he can get upset, Neil assures him that it is the most exclusive house in town. While they wait, Peter admires their respectable surroundings:

It was a generously proportioned room and the upright piano, the victrola, the chesterfields back to back, the comfortable chairs and the rich rug might have decorated any bougeoise living room. For a brothel it was on an elaborate scale, vastly different from the houses in the old segregated district [further east, visited earlier by Peter and Tony Dodds]. 'This is where the big shots have their fun, 'Neil continued. 'She's very particular and she knows everybody. She doesn't even let the girls stay here. She telephones.'

While they wait, Peter enjoys his champagne: As the new wine sent its giddy vapours spiralling up into his head, Peter experienced a simultaneous volte-face of spirit. Now I'm beginning to see life, he thought, developing enthusiasm for the adventure. This is life. This is why I came to a large city. This is experience. I don't have to go all the way and yet I can learn something. (p.80)
The girls arrive. Both are French Canadian. Neil has met Anette before; she sits on his knee and they talk in French. The second girl is dark-haired, quietly dressed, pretty, like the office girls Peter sees in the trams. Her girl-next-door attractiveness is fatal to Peter's resolve merely to window shop. They warm up on champagne. Neil and his girl disappear upstairs. Peter's girl is named Jeanne. They speak English. She asks:

'You like me?' Her soft dark eyes regarded him anxiously. His blood was in a tumult. He tried to answer, but his heart beat hollowly in his throat and he didn't dare speak. As he nodded his head, she gave a little sigh of satisfaction and laid her dark head on his shoulder ... Only half-protestingly, he allowed her to lead him by the hand, like a small boy, up the stairs. He stood in the darkness just inside the door, shaken by the fierceness of his own desire, as she fumbled for the lamp on the bed table. When she turned up the light, he lay down shivering on the bed. She lay down beside him, laughing a little, and put solicitous arms around him.... Years of repressed emotions welled up in him, shaking him like a reed in a strong breeze. A long sigh escaped him and his arms tightened around her. He was gone now. He couldn't think coherently in the grip of something stronger than reason. It was delicious to yield. (pp.81-82)

Peter wakes up in the house alone, hungover, filled with loathing ... for everything that had happened (p.82). He creeps out of the silent house, terrified he may have caught a venereal disease. Fortunately, he has not. ${ }^{20}$ The episode amounts to a critique, however unconscious, of society's consignment of sex to the extremes of marriage, illicit affairs and brothels. The consequent division of women into respectable and loose in turn fostered the attitudes which Peter had noticed among his fraternity brothers. They pursued (or pretended to pursue) women of uncertain reputation, but scorned (or at least pretended to scorn) encounters with respectable girls from their own milieu. 


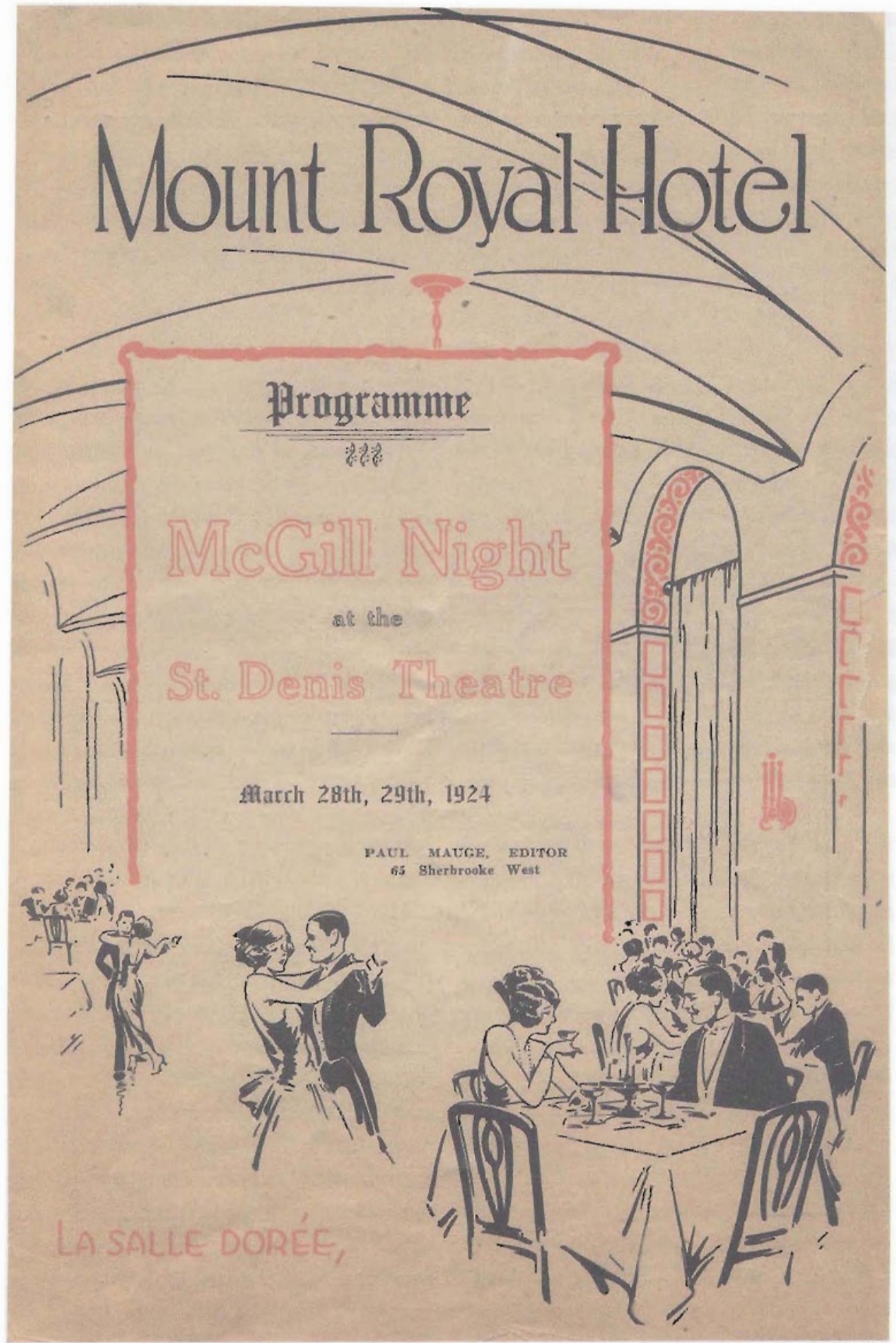

Figure 15. The heavy fragrance of perfume and powder mingled with the scent of tobacco. 
There was a tradition around the house against'softing.' Going to debutante dances or to social affairs of any kind that were eminently respectable came under this general heading. Rho Delta was the only fraternity on the campus that did not give an annual dance, and it took pride in its reputation of never having had a female cross its threshold. Other fraternities were ridiculed on this score. 'Fancy guys,' the Rho Delts said in disgust... Let a man put on evening clothes and he was immediately the target for catcalls and raspberries. But the fact remained that they did put on evening clothes.

Reluctantly, they accepted invitations to dances, but always proclaimed they had no choice; the hostess was a family friend, or married to a business associate of their fathers or summered in the same place.

However, let it be known that one of their number had been seen with the dancer from the Venetian Gardens, or some other girl of racy reputation or such status in life that his intentions could not be mistaken, then his conduct was generally commended (Figs. 16,17). He was a 'smooth performer', 'a card', or 'a terrible man.' It was pose clear through, yet some of the younger and more impressionable lads were taken in by it. It was, too, the kind of pose that was very easy to adopt after being exposed to it every day for months, as Peter discovered... Later, he found that decent girls were attracted by men who were known to cultivate questionable women. That was a problem that constantly stumped him.... he could never quite make up his mind whether it was because they offered a certain amount of danger and were therefore exciting companions, or because they were almost always men with easy, pleasant manners who knew how to be agreeable and entertaining. (pp.50-51)
These contemporary attitudes, with their contradictions, were about to change, to some extent. This change is reflected in novels after 1940, including some set in Montreal, which drop the double standard. Brothel episodes give way to premarital sexual relations between equal partners, who usually plan to marry eventually. For example, in the best seller Earth and High Heaven (1944), Gwethalyn Graham's heroine (incidentally, a McGill graduate) slips up north to the Laurentian mountains (the preferred getaway spot for such encounters) for a romantic interlude with the man she intends to marry. ${ }^{21}$ This evolution may reflect the uncertainties of the Second World War, spurring people to experience life to the full while they could.

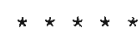

Meanwhile, the snow runs off the mountain; April rains are over and spring exams await. Students occupy every chair in the Redpath Library (its stacks expanded in 1922 to hold an ever-growing collection). The students are distracted by a thousand sounds and smells which float through the open windows to distract the brain-straining seekers after knowledge and degrees. A fife-and-drum corps passing on Sherbrooke Street lifted weary eyes from the printed pages, and the medlcy of automobile klaxons, snatches of laughter under the windows and shouted conversation across McTavish Street broke in on three hundred reveries.... Spring is not the best time of the year for mental concentration. (pp.85-86)

The fraternity studies and sunbathes. Peter and his English roommate Eric wake to steamship whistles in the harbour. Ever ready for a break from studying, Peter walks with Eric down Beaver Hall Hill 


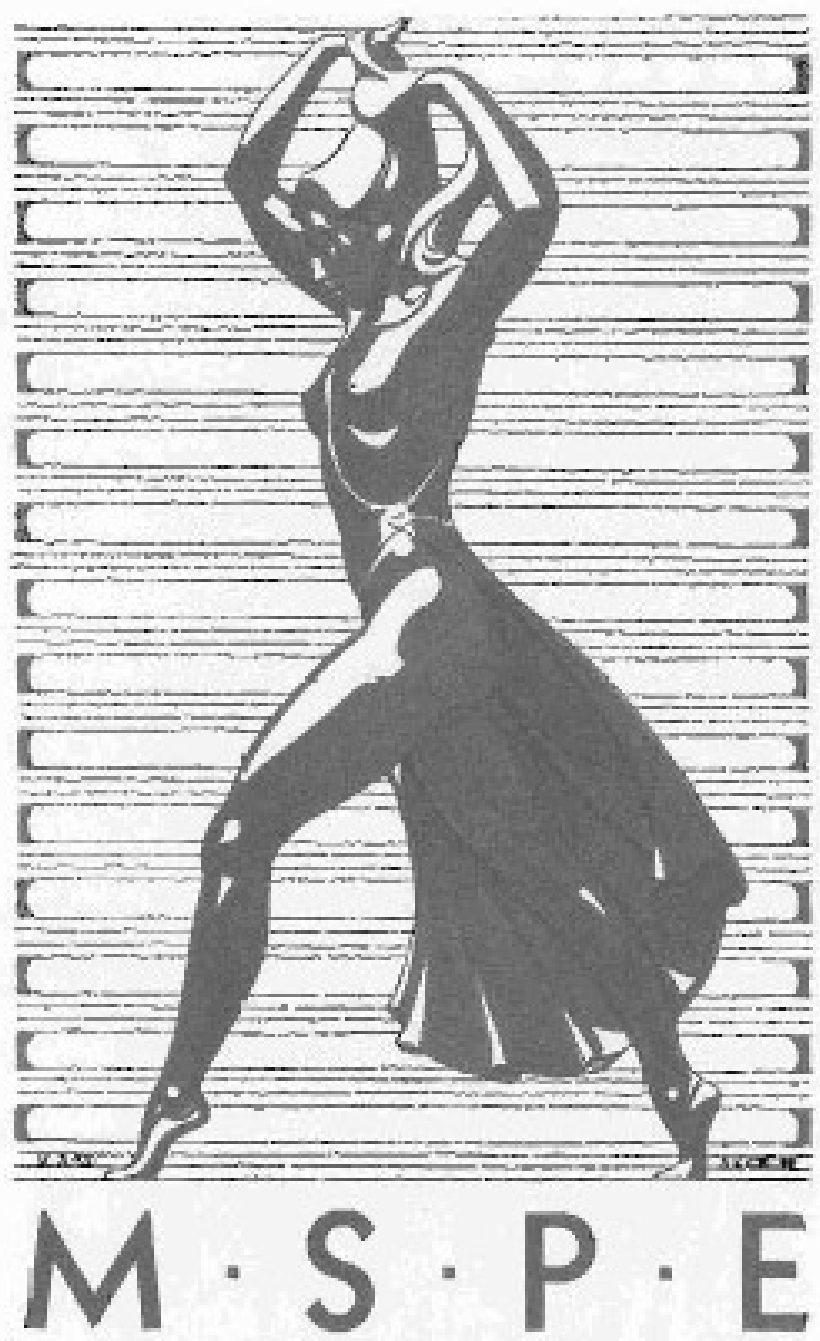

Figure 16. Seen with the dancer from the Venetian Gardbx.. Drawing by R.A. Montgomery, Arch. 1931.

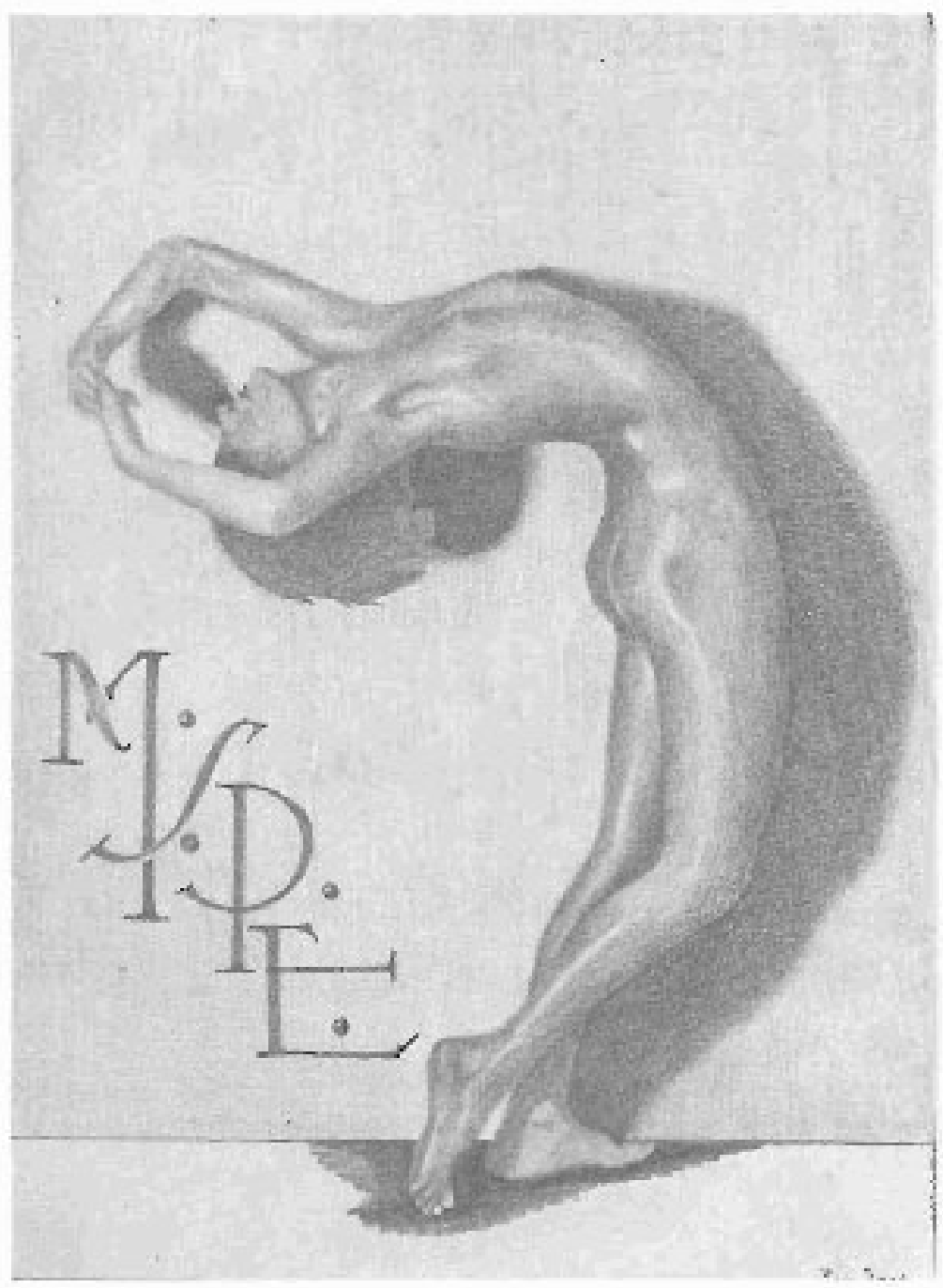

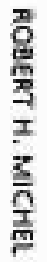

Figure $17 . .$. cr some ather girl of nacy reputation. Diawing by Pic Ross, late 1920's. 
to the heart of the city to the port to see the newly arrived ships. In the 1920 s, Montreal was still the main shipping and commercial city of Canada. It is Peter's first visit to the old mercantile part of the city, by the St. Lawrence River, a mile or so from McGill.

He was amazed by its solidity and compactness. It was like another city entirely. The streets were narrow and the traffic all flowed in one direction. The imposing structures of banks rose sheer from the sidewalks. Flat-topped limousines, businessmen's cars, were drawn up along the curbs. (p.86)

They walk from Place d'Armes towards the waterfront. They can smell the spices in the warehouses:

Heavy trays bumped noisily along the cobblestones on Common Street [rue de la Commune]. Men stood in knots before the taverns and cafes and a crowd swarmed in front of the Sailors' Institute. They heard overseas dialects on all sides. Above the cement wall that cut off the wharves from the street were the shipping companies' signs: Cunard Line, White Star Line, Canadian Pacific Steamships. (p. 87)

Eric suggests going to the Canadian Pacific ship dock, where he had landed last fall. They cross through the tracks with their freight cars, go around massive concrete grain elevators and into a long shed.

The place was a hive of activity. A passenger liner and two small freighters were in and men were busy unloading cargo. Boxes slid smoothly down chutes and were arranged in neat piles along the walls. Winches dipped suddenly like gulls into holds and came up with their catch. The stevedores shouted and sweated... Eric and Peter slowed down and peered at the printing on the casings. Crockery and textiles from England. Matches from Sweden. Anchovies from Norway. Soap from France. They sauntered on to a pile of domestic freight waiting to be taken aboard. Automotive parts and breakfast cereals from Ontario. Cheese and aluminum products from Quebec.
Peter felt his economics course coming magically to life (Fig. 18). [p.87]

Eric sees the ship, The Montcalm, on which he had crossed to Montreal. They go aboard. The purser, Murdoch, remembers Eric and lets him show Peter over the ship. Murdoch pours them gins and bitters and spouts on international affairs with all the confidence of the literate seaman.

Murdodh.. discussed the world as if it were his own backyard, while they sat and marvelled. To him, Africa was the fascinating continent. It was so big it presented every imaginable phase of life. Europe, he said, was finished. It was over-crowded, its countries too self-coriscious and its politicians too unscrupulous. Ghandi was going to make a mess of trouble for the British in India. Australia was wonderful, but the people were lazy and luxury loving. China was a hellhole. Disease and ignorance were rampant, you never knew when you were going to find yourself in the middle of an earthquake or a flood, and the interior was flooded with bandits. The laps were clean and progressive, though not always trustworthy. Their main object now was to replace their old civilization with a western one and they aped the Americans in everything. That was funny when you considered how much Japan hated the United States. Canada, he thought, was a fine young country with a great future - the exact antithesis, so to speak, of European countries. South Africa, Canada and the Argentine were the three countries that impressed him as having the most promise. (pp. 89-90)

Peter asks Murdoch what he reads and Murdoch declares for Pope, Kipling, Masefield and W.W. Jacobs; he feels that Conrad doesn't write about the sea as I know it (p.91). Afterwards, Peter and Eric look longingly at a Cunarder making dock, its band playing, while passengers crowd the rails.

Peter thought if he ever made any money he'd stop work, pack his bag and go on a non-stop journey that would take him in and out of strange ports forever, preferably 


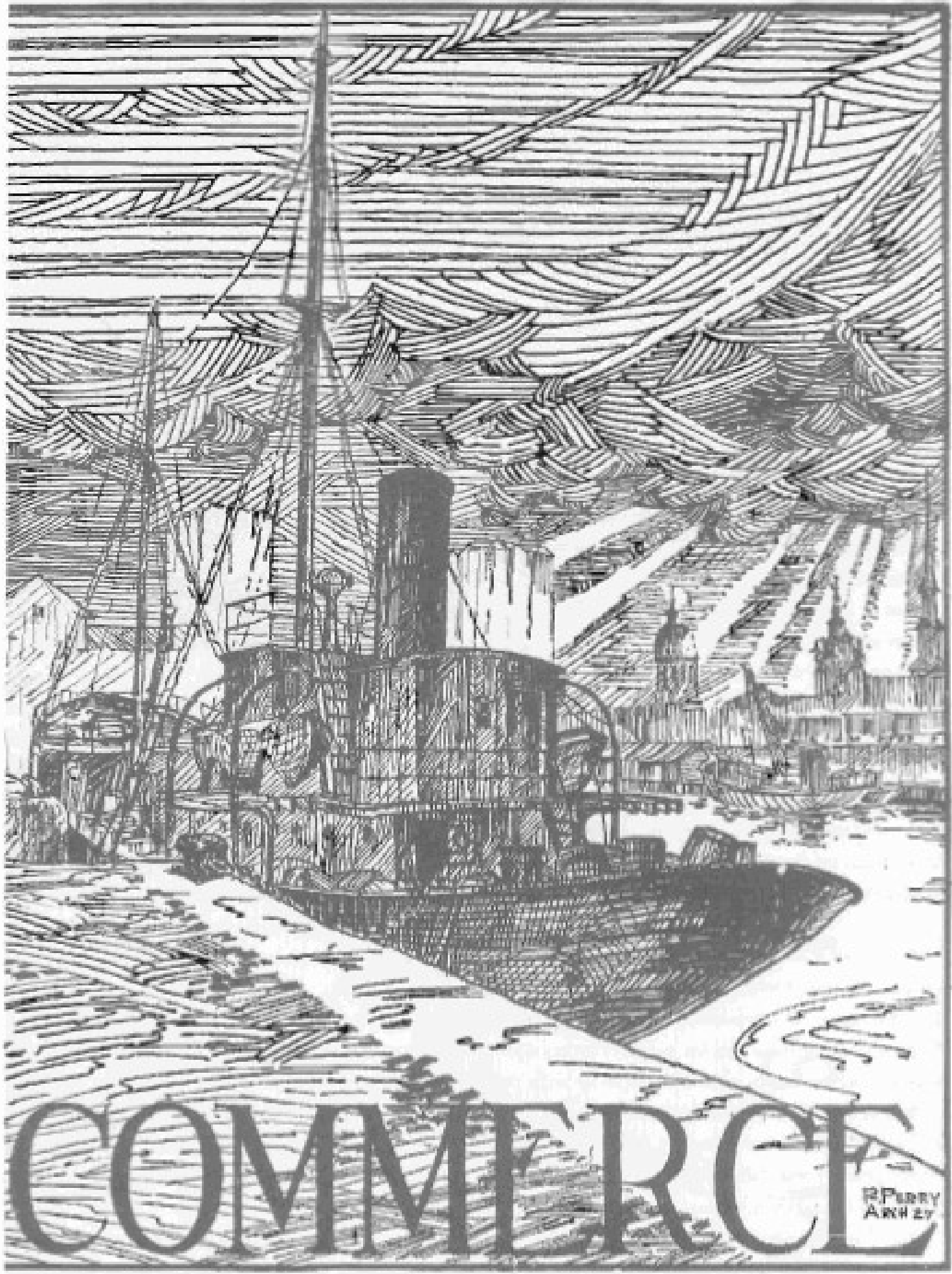

Figure 18. Peter felt his ecanomics course coming magically to life. Draring by R. Perry, Arch. 1927. 
in the company of a man like $\mathrm{Mr}$. Murdoch, from whom the warld with heid few secrets. It was the mast pleasing method of acguiring an education and was, at the same time, a ciean and satisfying way of spending money. It was a wonderfui world, packed with beauty and adventure for the imaginative; only the dult found it humdrum and oppressive. The spirit of spring was like wine in his blood, giving a lift to his imagination and colour to anything his mind played upon. (p.92)

Mutdoch's ship will return soon and Eric plans to take it bsck to Europe for the summet break. Peter and Eric drop into the Neptune Cafe, full of sailors and riffraff out of a Dos Passos novel who, Peter thinks, have more fun than people chained to a desk. What does Peter want to do this summet? Idan't know. Travd - or foll in love - anything but lie in a hammock with a book all summer. Peter wonders if reading is a poor substitute for living. A woman would be preferable, of course, Eric agrees dryly (p.93). Eric and Peter agree to move into digs together next year; they have. had enough fraternity regimentation.

$A$ lirtle later, sure he's done adequately on his exams, Peter drops into the Pig and ends up drinking with Titn Manson, the fraternity brother from the Canadian West, who had been dumped in the frcesing tub for suggesting that new men be tteated better. Tur is fed up with the cast, MeGill, the Rho Delts and the whole snobby ouffit,... Tecome from a part of the country where people are honest and straight-forwand - at least $I$ think they are. They don't say one thing and think another.... $I$ understond now', $N$ m went on with an extravigant gesture, "why our public men out there are so bitter against the cast. The bastards are so slick you nover know where you stand with them. Promises mean nothing. If you take them seriously the joke's on you. Laok at the fraternity's initiation ceremony. Do you know I was fool enough to be impressed by it.?' (p.96)

In spite of Tim's dis!llusionment, when Tlm parts for the West, they use the fraternity's secret handshake. Peter contemplates this outburst of Canadian regionalism; he realizes Tim hates the lack of ideal- ism as well as the competitiveness and opportunism saudents pick up at McGell and pursue for success in later life. Tim reintonces Peter's scepticism towards his world at MoGill yes, at the same tirse. he is annoyed at Tim for disturbing his complacency. Peter adenits to himself that he wancs to jotn the successful crowd, whatever their faults may be.

Celebrating the end of exams, Feter is picked up by Don Horwill and some girls in a car Among them is Anne Somets, whose table at the Ritz-Carieton he had crashed after the footbali dinner. She is to marry the nexe week, but mean while is bent on a good time and specially asked Don to bring Petec. She says, Ia ghing at his surprise, forilened you, ith Aize, so pew 'd better ride with me.' Peter asks where the groom is. In Atlantic City - resting.' They drive to the cathet passe Venecian Gardens rather chan a tashionable hotei where Anne's crowd might recognize her partying sans fiancé. They have a bottle ot wine. Don was

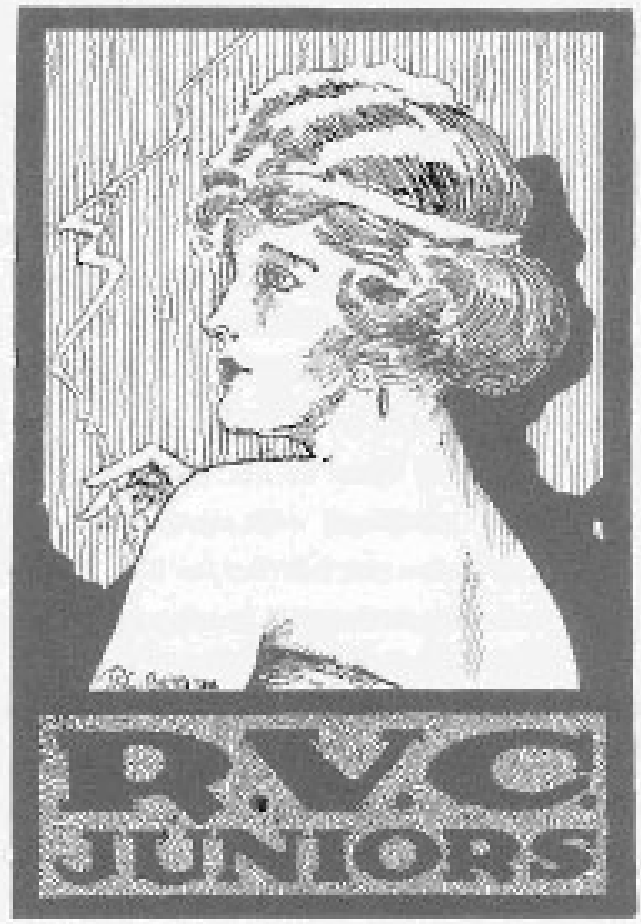

Figure 19.

Peter confined his arecotions almast exclusively to anne...

Drawing by R.C. Betes, B.Arch. 1928. 
giving the girl with him a mild nush. They were friends of long stanting, and she had come up from Toronts to be one of Anne's bridesmaids. Peter confined his attentions almust exclusively to Anne (p.100) (Fig. 19]. On this elusive note the stary of Peter's first year ends.

\section{SEQUEL: PETER'S SECOND YEAR}

The novel continues with a fragment of Peter's second ycar, mainly his date with a beautiful American college girl. Peter and Eric have moved into a flat. The sequel hints that Peter's life will be less MCGilland fraternity-oriented, possibly romantic. It is already Novemher; Peter can relax now that football and training tables have ended. Peter has time to read, loaf and have fan. He continues the success. ful strategy he adopted after his disaster in his exams the previous year. By spending two hours a day in the library, he can pass his courses and kecp his evenings frect to read or go out.

Afriend, Bis! Bjalkic, invites him to a charity ball, preceded by dinnet at the Blatkles' grand house, It is a last minute thing an extra man is needed to escort a visiting American gitl to the ball. Peter asks what she looks like; Blatke does not know. Peter recalls that most American girls he has met have been artractive and accepts. Luckily, Eric has gone out to a film 50 Peter helps himself to Eric's evening clothes, making a mental note to have them copled by his own tailor. His gltl, Betty Parker, tutns out to be a real beauty: She cumbined, with startling effect, dark skin and yellow brown cyes with her fair hoir. It gave her a pectiliar and erotic distinction. Her fact was oval and when she smiled he caught glimpses of fashing, even tceth. There follows an elegant meal of soup, oysters and chablis, chicken and white burgundy, a salad and champagne, and cheese... In the shadowy candle-lit room, the light gleaned brighrly on their starched shirt frouts, the bare arms and shoriders of the girls and the shining silver (sequel, p.4). Peter decides there is a lot to be said for the formal side of gentility.

Betty pleases Peter by saying she has heard that he is not only a football hero, but intelligent as well.
After they have dtscussed modern writers, Peter flatters Betty by teliting her she is notonly heautiful, hut so incelligent she is almore a bive stocking. They depart for the ball at ter. Peter feeis serongly attracted to Betty She has brains and beaury. They dance:

Like ather Anserican girls he had known, she was an extrendily conspetert dancer.... She was stan and almost his own height and their nurvements shackinaized perfectly. He was conscious of the strage, intuswe scent

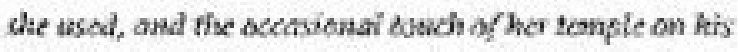
check as the haked nhout. Theig immediate intimacy, legitivtised by the maden dance formo, aimot task his breatit awas (Fig-20). (sequel, pp. 7-8)

Berty enjoys being Necer's datc. She is grativied by how many prople greet Peter - and then rowice het. After the ball, at midnight supper se an unnamed Hotel, she discovers that Peter would tike to write some day. He icarns she is reincteen, goes ta Semith College in Massachuserts, and is inecrested in books, the theatre and travel. She thicks Canadians spoak

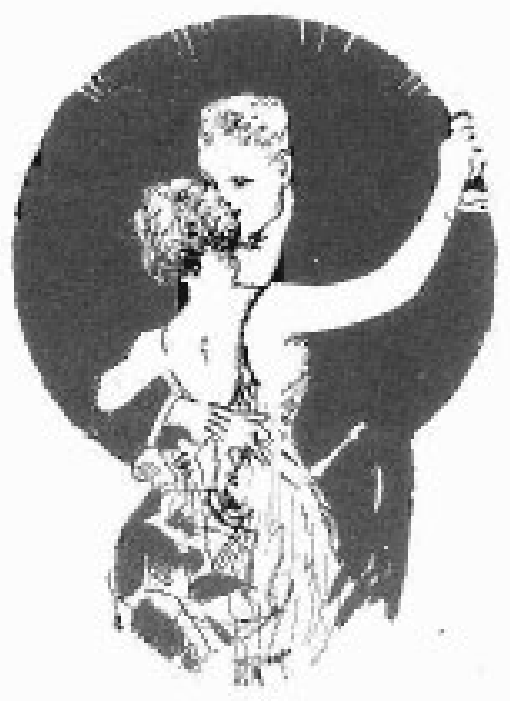

Figure 20. Their immediate intimary, fegitimized by the noriem dance forms, almost task his breath away. Diawing by S.E. Koot. 
with an English accent and that the men are mote mature than their American counterparts - more like Englishmen:

Back home all the men sesmed to be interested in was fimishing everything that was in the botrle, driving fast can and manding their sol/scoves. Every party wess spoiled becatuse the men all gathernd in a roem and drank, and talked about goil or the stock manket. She guessed that prohibition [srill in effect in the States until 1933) might hove hod something to do with it. Chilizen society seemed to have disopseared with the introduction of the Eightemth Amendment. (sequel, pp.8-9)

Looking at the othet supper lables, she asks Peter to point cut the celebrities. The Governor General, who is also the Visitor of McGill, is there [Viscount whingden, G.G., 1926-1931), Eerty says, Hels a boockout, isnz he? He look's awfully distinguished (Fig 21). She thinks the McGill Chancellor [Edward Beatry] has a nice, strong face (Fig. 22). Peter points out equernes on the Governor General's staff: Some of thom hrve tities and enterprising young Canadian pirls ofter marny than. Retty hopes Canadian sociery is based on ritles or at least something inore glamorous than money making in Boston or Nee York it's afways Mr. So and So, the Buckwheat Xing, or the Steel Magnate or the Motor Manufachurer. Peter disillusions her; maney nuns Canada as much as it does the United States. Betty persists: That may be mas, but when I'm anywere in the British Empiry I can't help but think of its traditions, I can feel the difference. Tell me, whar's Quebec City like? (Sequel, pp. 9-10)

Berty is headed to Quebec Ciry the next day. The manuscript ends here. Had it been completed, a romance might have budded or Peter might have met some of McGllt's women students on the steps of the Arts Building, a popular gathering place. We leave Peter, one hopes, with a life as long as his creator's, the Depression and wat ahead, but good times tno, in the vibrant ciry of Montreal.

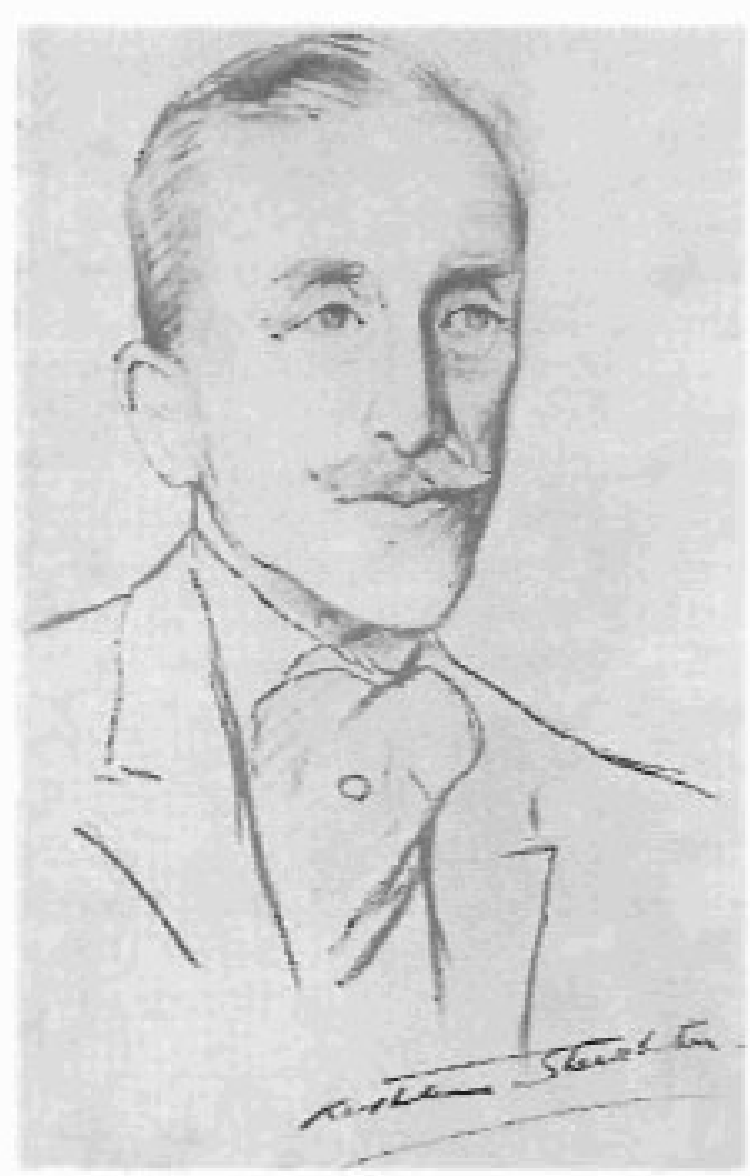

Figure 21. He's a knockout isn't he? He looks anfully distinguished. Viscount Willingdon, Visitor of McGul, by Kathlcen Shackleton, late 1920 s.

While Carroll excelled at short pieces, he may have found a novel too long or did not know where he wanted his story to go. Still, he serves as McGills Scott Fitzgerald, its chronicler of foothall fraternities and student social life in the 1920s. Canoll touches on most other traditional college novel themes: studies and ideas, student diversity, yearning for travei, and exposure to sex and weslth. While some college novels avoid identifiable settings in an attempt to 
be universal, the best-known ones are set in real places and times. Peter Rice's story is inextricable from its snapshots of the McGiil campus, Montreal's port, the Student Union (Fig. 23), the Pig and Whistle and the Red and White Revue. His enthusiasm for Montreal reminds us that students choose MCGill partly for its location. The story touches specifically Canadian themes: Montreal's importance as a port and its nightlife, Toronto's dowdiness, Canadian regional allenation, Montreal's French-English chasm, Btitish and American misconceptions of Canada, and the Anglophone beilef that the french were experts in matters sexual. And in its unique fictional porttayal of Coach Shaughnessy and iootball practices and matches, the novel foreshadows Carroll's nonfiction writing about sports and sports characters.

Peter's friends werc McGull types of the 1920s: Don Howell - football player, fratetnity man, regalar gury and role model; Tony Dodds - subversive intellectual and tempter; and Eric Mowat - British, amiable, with an outsider's view of Canada. While Tony was Canadian, the three other characters symbolizing sophistication, Eric, Neil and Betry wete brought up outside Canada. The despest study is of Peter himself - very Canadian, the easy-going, enigmatic observer, athlete, partygoet, and aspiring writer. Peter and his friends disprove the idea, found in many college novels, that college makes the man. McGill offers learning, experience and Montreal, without the lifelong molding attributed to Harvard and Oxford. While Peter loves McGill, he criticizes its weakness in literature and the arts and his fratemity's hazing and contempt for dances.

Carroll's novel reveals both the American influences on old Scots-inspired McGill and the growing similarities of college culture across the continent at the time. By the 1920s, McGill aspited to a huge, American-style physical plant, extending beyond basic classtooms and labs to all aspects of student life - gymnaslums and stadiums, theatres, convo-

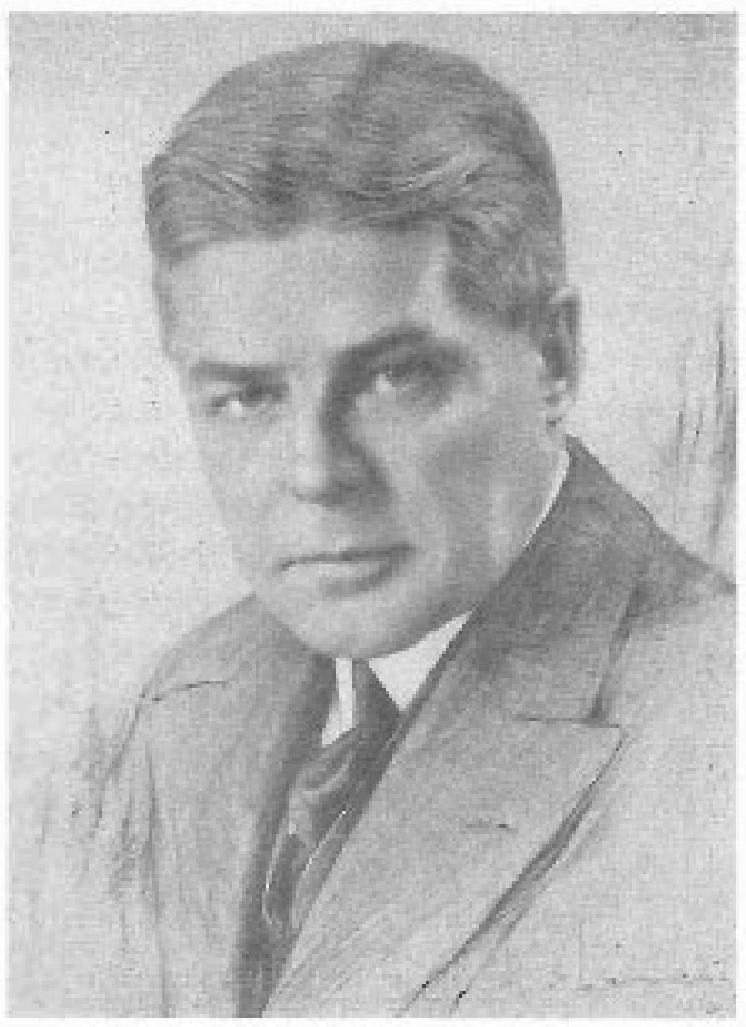

Figute 22, Betty says McGill Chancellor Sir Edward Beatty has a nice sbons fitce.

calion halls and grand residential quads. Percy Nobbs, McGill Architecture professor, unsuccessfully proposed plans to transform the haphazard campus of the 1920 s into a Shangri-La of collegiate monumentality. (Instesd, it would be the French-speaking Universite de Montreal on the other side of the Mountain which would build the city's utopian campus, designed in yellow bricik Deco by Ernest Comier.) Like American universities, McGili expanded its curriculum of courses in arts and science and the traditional professions, law and medicine, in response to utilitarian demands for training in such developing protessions as commerce, nursing librar. ianship, teaching, home economics, and scientitic 


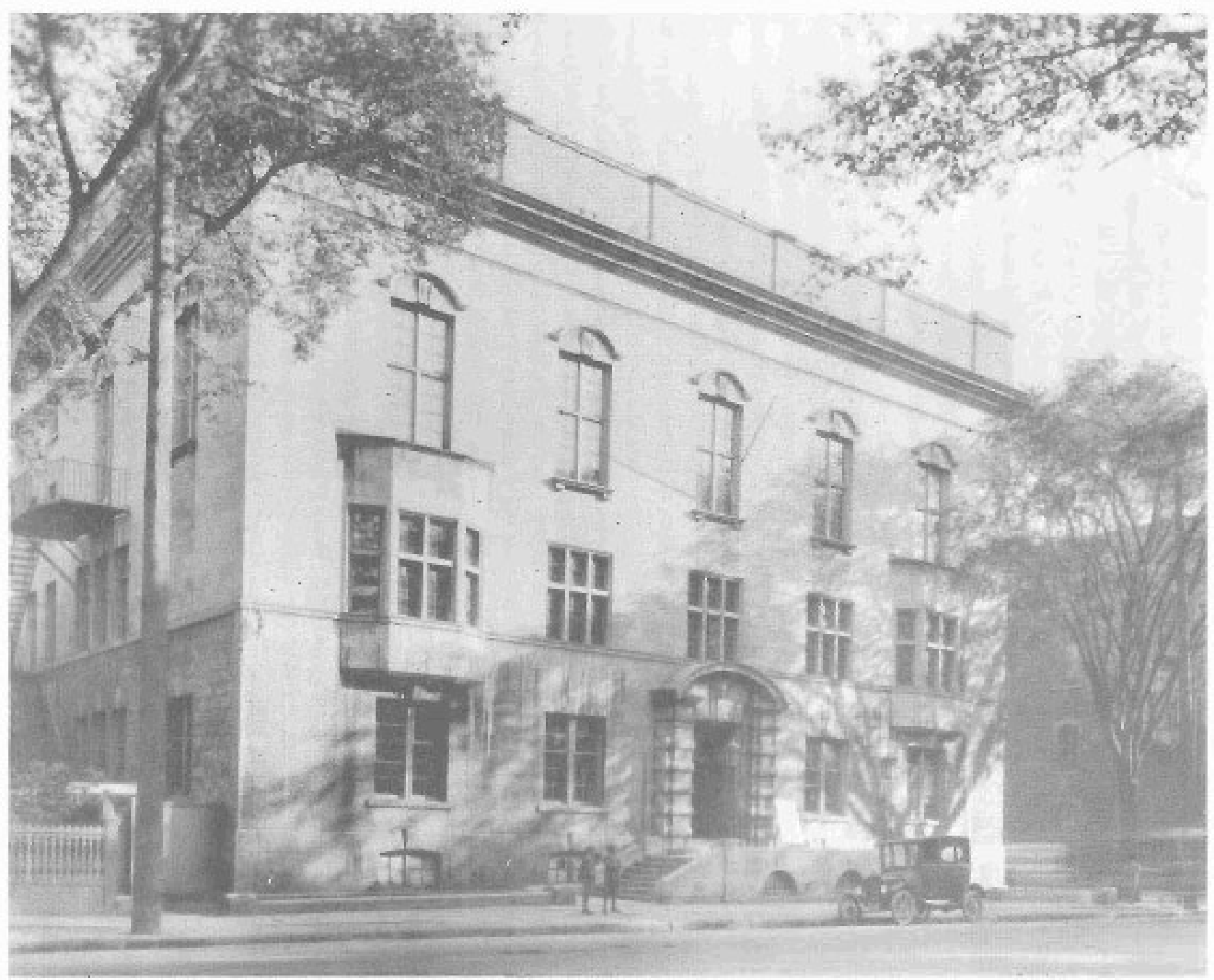


agriculture. 'The most obvious American influence was VicGill's American Greek letter fraternity system. McGill also lad aciopted the American football ethos as good for alumni relations, fund-raising, and for the players themselves. Carroll noted of football's spokesman, Shaughnessy: "Many of the young men he coached at McGill went on to become leadcrs in their criosen fields: industry, finance and the preiessions. Ile never forgot any of them and it's safe to say that none of them ever forgot him."22

Traditionally, university experiences have been similar the world over; students attend iectures in specific places, whether surrounded by meadows or raveriss. Democratically, distance learning and night school extended the university beyond its old constituency of youth and the iesured or wealthy. Now the Internet seems poised to compete with, even replace, the university (which is a geographicaliy and physically cafined place with its storehouse of books and professors) with quick, free knowledge from everywhere on earth. If economics can be learned electronically, anytime, anyplace, will there still be a need for a Leacock in his tattered gown in room such-and-such in the Arts Building at 1.1 A.M.? Technology may threaten traditional campus-based learning but the university coming-of-age experience celebrated in college novels and by Carroll will probably survive - not only in front of computer screens, but also inside the old grey buildings of McGill, where Peter, Eric, and Tony went to classes and dreamed of their lives to come.

\section{POSTSCRIPT: JNK CARROLL}

Carroll put his passion for sport, literature and quiet observation into Peter Rice. The novel was unfinished, but Carroll's life offers a denouement to Peter's literary ambitions, the life Peter might have led had he existed. Austen Joseph Carroll (nicknamed "Dink") was born in Guelph, Ontario on 12 November 1899 and died in Montreal on 8 April 1991. His father was a teacher and lawyer from County Cork, Ireland. As a youth, Cartoll played golf, baseball, football and boxed. He played backfield for the Guelph Collegiate Institute in the Dominion Finals in 1918 against the University of Toronto. After a year at Toronto, he came to McGili in 1920, zight after McGill under Shaughnessy won the Canadian university football championship (Fig. 24). In 1987 Carroll recalled this 1919 team which opened Molson Stadium as "unbeaten, untied, and its goal line never crossed." Though McGill teams did not win the championship during his own years, Carroll was a star player. The McGill Daily (7 Nov. 1922) described Carroll, who played, as required, quarterback and halfback: "by far the outstanding player on the McGill team... His punting was steady, and his return of kicks nothing short of sensational at times, but the department in which he excelled was in running through broken fields for long gains..." Carroll's football episodes at McGill were long remembered; in 1969 Judge Hank Gaboury suggested: "Have Dink relate how he saved the day for Old McGill back in 1924 [1922?] when he made a running catch of a 75 yard boot by Warren Snyder that would make Hal Patterson look like a rookie." Quiet, Carroll was called the "Whispering quarterback "and a "phlegmatic phenomenon." He was light for a player, weighing so little (140 pounds) that "If I was going anywhere, I had to get there in a hurry. I needed acceleration." 23 After graduating in saw in

23 Dink Carroll, "McGill win stirs ghosts of 1919 team," The Montreal Gazette, 31 Dec. 1987 (on McGill's winning the 1987 collegiate championship Vanier Cup, coached by Charlie Baillie, whose father Don was on the 1919 team). On Carroll's playing, see also MCGill Daily, 28 April 1923, 3; Gaboury to Mr. Moss, undated, file of letters on the occasion of Gazette retirement dinner for Carroll, 16 Dec. 1969, Carroll Papers, MG 4151, C.4. A third-year law student, M. Gaboury, wrote a skit for the 1925 Red and White Revue; Old McCill 1923, 93; Tim Burke's column, The Montreal Gazette, 7 Nov. 1980.

24 Letter from Victor F. Obeck to Carroll, 10 Sept. 1949, Correspondence, 1945-1949, Carroll Papers, McCill University Archives, MG 4151, C.5; Zeta Psi House Account bill, 27 May 1937, Correspondence 1935-1939, Carroll Papers, MG 4151, C.5 
1923. Carroll kept in touch with McGill and occasionslly boarded at Zeta Pst's elegant new house; opened in 1923, designed by A. T. Galt Dutoford. He helped Vic Obeck get the job of McGill's Director of Atisletics in 1949 (and with other foumalists) promoted Obeck's program ${ }^{2 t}$

Instesd of practistog law, Carroll worked in sports organizations, including, apparenty, the Toronto Maple Leais kaseball Club, and passibly in atwertising and investing as well; his early working life is not documented in his archive. According to his author's blurb in Esquire foe his story "The Amateur," (lanvary 1936 , p.14), following graduation, he had worked in the publicity departrent of the Canadian Pacific Raitway, then for an advertising agency, and more tecently as a sports journalist. (The MoGill novel includes a dig at the CPR's Indians-and-cowboys advertising of Canada, swallewed by Eric; Carroll also wrote unpublished fiction set in advertising.) Montrat Gazelts sportswriter Tim Burke resalled that Carrolt has always been lured by the romance of writing: "I guess if you read a lot, like $I$ did, you want to start purting sometzting down yourself" (said Carrol);. According to Burke, untet the Depresston, Carnoll led a carefree life in Montreal, writing advertising copy "and having a rosting good tme around town with his pals from McGill." Carroll observed that betound the Depresston uaumatic bur educatiocal, uprooting him, delaying his marriage, and teaching him that simost everyone needs help some time of another it the Depression, Cacrall set aut for Toronto and wrote freelance. ${ }^{25}$

Cartall came into his own as sports editor at the Mantreut Gazette from 1942 to 1969; be contributed articles until 1987. In his matden columrr on 13 July

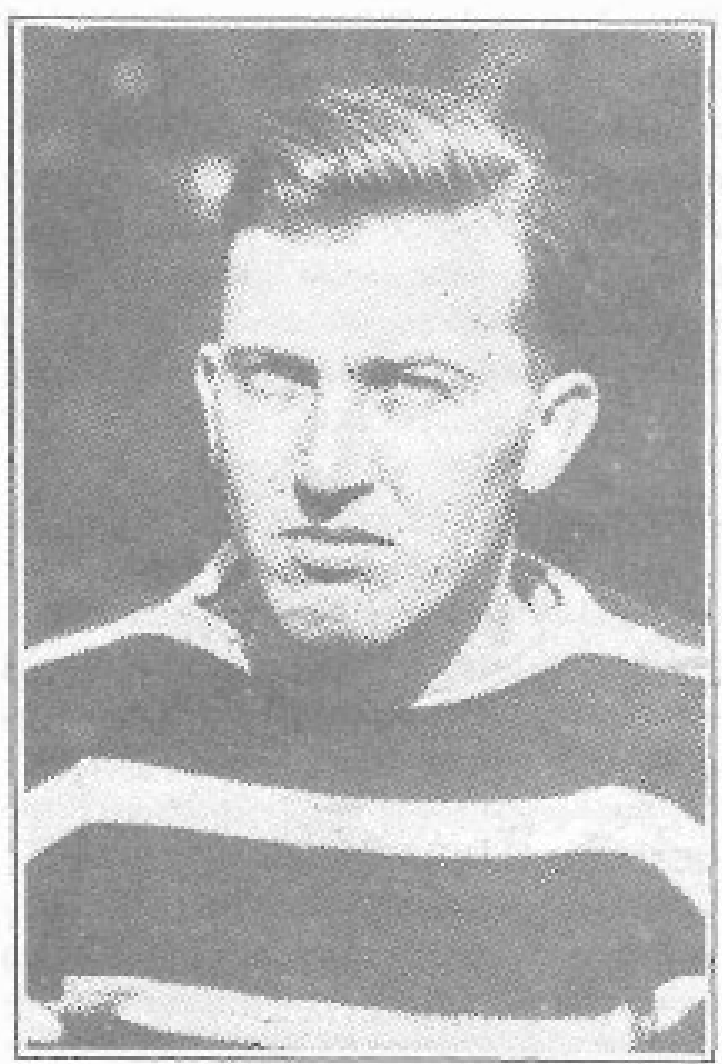

Figure 24. Dink Currot, McGill Footbal! Team, ca. 1921.

1942. Carroll told how right aster gradtracing from McGill, he had nearly gotten a job on the Gozate undt he was asked if he had worked on the MoGill Darly. Carrall replied, no, he'd been too busy, once foothall seasons were over, trying to eatch up with his class work. So a McGilf Dailh alumsnus got the job instcad. Canoll added that despite this serback, he never ateayed iar from the sports ileld, which fascinated him: "The sports worid is an exact replica of the gitest world, only smallet, ${ }^{-26}$ As Gazette sports editor,

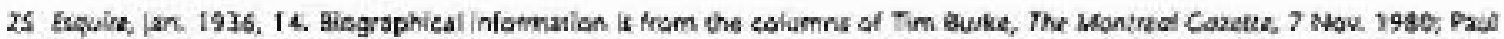

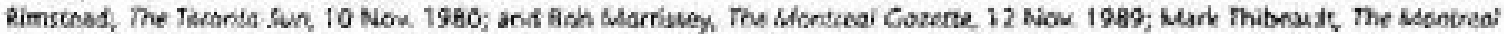

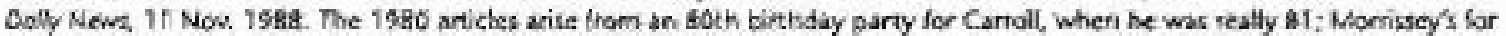

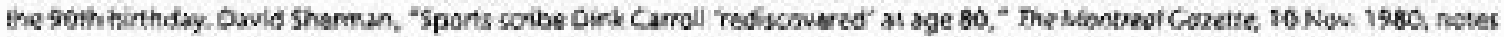

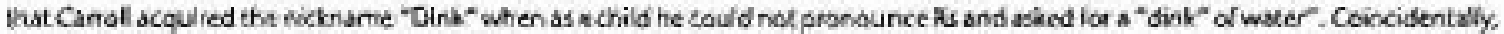

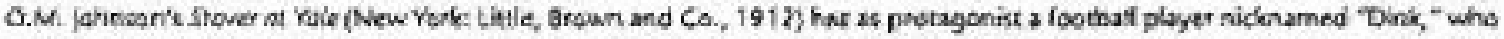

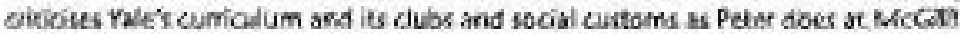

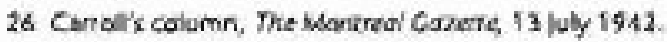


Carroll tlourished in the Montreal of the 1940s and 1950s, eloquently cxhumed by Willian Weintraut) irl Citv Unigue (1996), who describes late-night diring after hockey games at Slithin's and Slotkin's, a sports and journalists' hangout where "Morley Callaghan, in town fron Toronto, would sit lor hours, drinking with his pal Ijink Carrol] ... and avid]y absorbing local colour for use in the novel he was writing about Montreal." Carroll and Callaghan talked about their writing; perhaps they cliscussed Carroll's MoGill stury or Callaghan's own university novel, set at loronto (The Varsity Stur); 1948)

(arroll's colle âgues admired not on ly his clear writing but his gentlemanly attitudes. His obituary' calls him "a warm-hearted columniss who wrote with clarity and avoided embarrassing a fumbling athlete." It had an anecdote from Brodic Snyder about one of the few times Carroll's column causcd offence something about wrestling. Two "huge and ugiy" wrest]ers showed up in the sports department of the Montrea! Gazette, lale in the day when Dinli was working alone: "One of L.re guys inquired: 'Dink Carroll?" Dink sized up the situation in a moment and said; "Sorry, he left for EJorida on vacation this moming."'28

Carroll married Margatet (Peggry) Porter, from liredericton, N.B. She would later be a reference librarian at Mcrill, guiding gererations of students (including the present writer) through mazes of catalogues and bibliographical aids. Carroll's letters to her in 1.935, before they married, mentioned that he had been writing articles and stories and showing them to Moriey Callaghan: "Do you realize that, at the rate I'm going, I'm doing almost a piece a weck, either an article or a story?" " Peggy Carroll wrote about her husband and his sportswiting methods in 1991, not long after his death:

"He had a fantastic memory... the athletes, thejr managers, etc. spoke freely before Dink \& he clid not take notes. For example usually on Saturdays when teams arrived for the weckend games and ofter stayed at the Mount Royal Hotel, they talked to Dirk quite freely. Vo tape recotders thern. Ile was often alerted to their comings $\&$ goings by a character 'Jockey Fleming' who loved the athletes because they often gave him a tip. He in turn would alert Dink (no tipping there). I can remember him interviewing such memoxable characters as Jack Adams, the Manager of thle Detroit Red Wingss - ancl many othors. These interviews woulu be used in hís daily columns. When Dink covcred baseball for the Royals International League team in Montreal, he sat up in the box \& kept the official scorc... Dink was naturally a wit \& a story teller \& there were so many odd chatacters around Montreal in those days. That was onc reason Morley Callaghan loved Montreal... He ard Dink were frierds in Toronto of course \& 1)ink used to rad Morley's stories over before he sent them out \& sometimes made suggestions for alterations." As dici his fellow joumalists, she notes that ner husband had the same literary spirit as the authors in his library: Granam Greene, Hemingway, Sherwood Anderson, Dos Passos and litzgerald."

Davic Sherman's account in 1980 of Carroll complements leggy Carroll's. Besides noting that

27 Williarr. Weintraub, City Unique: Montreal Duys and Nights in the 1910 and '50s (Toronto: Miclelland and Stcwart, 1996 ), 133. Callaghan's Montrcal novels were The inved und the Lost (Toronto: Macmillan of Cundada, 195i) and The Mury Colored Cont (New York: Coward-McCann, 1960); the latter depicts Slitkins and Slotkins, akout which see also Al Palmer, Munntreol Confideritiol, 33 -34; and Ken lohnstone, "Slotkin Rides Again," The Montreder, 37, no. .5 (May 1963): 24-8.

28 Dick Bacon, "Clariry, fairness Carroll's fortes" (obituary), Thie Montreal Gazelie, 9 April 1997.

29) Eetter from Carroll to Marcjarci Porter, posimarked 28 Alig. 1933; Ietter from Carroll to Margaret Porter (undated); and corre-

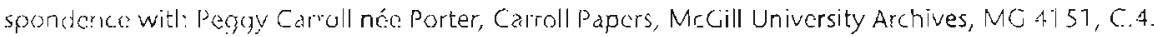

30 Letter from Peggy Carroll to Robert Michel (elien archivisi 'or historical records, MkGill), Cu. 3 July 3991 , in McGill Lniversity Arcnives Acression file 91-028. borkey Fleming's exploits als a Montreal character, who sang at stags and inveigled himself into most sports everits, are described in Al Palmer, Moritreal Confidentiol, 19-21. 
Hugh MacLennan and Mordecai Richler admired Carroll's style and literacy, he pointed out that Carroll turned down the usual sportswriter's perks:

"What set him apart from many of his colleagues was his rejection of the little brown envelopes and the out-and-out pay cheques many teams routinely issued to keep the reporters happy.... Athletes and coaches sought him out as a drinking buddy and confidant, knowing if something compromising slipped out between the fifth and sixth round of drinks at a hangout like Slitkins \& Slotkins on Dorchester Blvd., Dink could be trusted not to print it. 'Sometimes I tried to protect the players from themselves,' he says. Sherman noted that Canadiens coach Toe Blake called Carroll 'the most honest newspaperman I've ever seen." He avoided office politics and the office - 'You can't learn anything at the office,' he says." 31

Carroll may have been inspired to start a novel about McGill by Fitzgerald's example. But during his later career of nonfictional writing, he admired Hemingway for his natural style which turned sports in to literature. For both men, sports, like writing, meant overcoming obstacles with skili and valour. Carroll's papers include several Hemingway short stories, including "Cat in the rain" and "Big TwoHearted River "torn out of Hemingway's 1925 collection In Our Time, as well as Life and Time issues with cover stories on Hemingway. When Hemingway died in 1962, Carroll wrote admiringly of Hemingway's "fresh and original" style as well as his interest in sports. Carroll remarked that: "We met him only once and that in the Cafe Floridita in Havana four or five years ago. It was disappointing because it was three in the morning, he was tired after an evening with some U.S. naval officers and was on his way home. It's a matter of even greater regret that we can no longer look forward to reading more of his work, which gave us so much enjoyment." 32

Carroll was the rare sports writer who could hold forth on literature. A.J.M. Smith (one of the McGill "Aesthetes") congratulated him for his articles on Hemingway and Faulkner "as among the very best of the many things written on the deaths of those guys." Carroll's colleagues still recall his casual confidence; Gazette columnist L. Ian Macdonald recently referred to Carroll's "gift of the gentle putdown." Once Macdonald had argued "the case for Fitzgerald v. Ernest Hemingway" and Carroll pointed out he had discussed this subject with Hemingway himself, in Havana. ${ }^{33}$ Carroll's lifestyle may have had a touch of Hemingway's: a correspondent in 1940 asks "Who is the chap you knocked down in Toronto and made him call quits?" Carroll boxed in his youth and continued in a Montreal athletic club after graduation. When covering Canadiens vs. Rangers hockey in New York, Carroll would stop by Stillman's Gym and talk to the characters who hung about, sometimes putting them in his columns. ${ }^{34}$

At Carroll's eightieth birthday, columnist Paul Rimstead pointed out that unlike many sportswriters, who are frustrated athletes, Carroll would have liked to be a novelist like MacLennan or Richler. MacLennan praised Carroll's Gazette columns to his students for their concise, clear style and thanked Carroll for praising him in a column in April 1950

31 David Sherman, "Sports scribe Dink Carroll 'rediscovered' at age 80," The Montreal Gazette, 10 Nov. 1980.

32 Carroll's Montreal Gazette column "The Playing Field," subtitled "The Late Ernest Hemingway" (clipping, no date, ca. 1962); Hemingway stories: Carroll Papers, MG4151, C.2 file 5.

33 Carroll Papers, MG4151,C.6, Correspondence 1960-1964; L. Ian Macdonald's column, The Montreal Gazette, 5 May 2000.

34 Letter from Theo (no surname) to Carroll, 10 Sept. 1940, Correspondence 1940-1945, Carroll Papers, MG 4151, C.5. Rimstead, The Montreal Gazette, 12 Nov. 1989. 


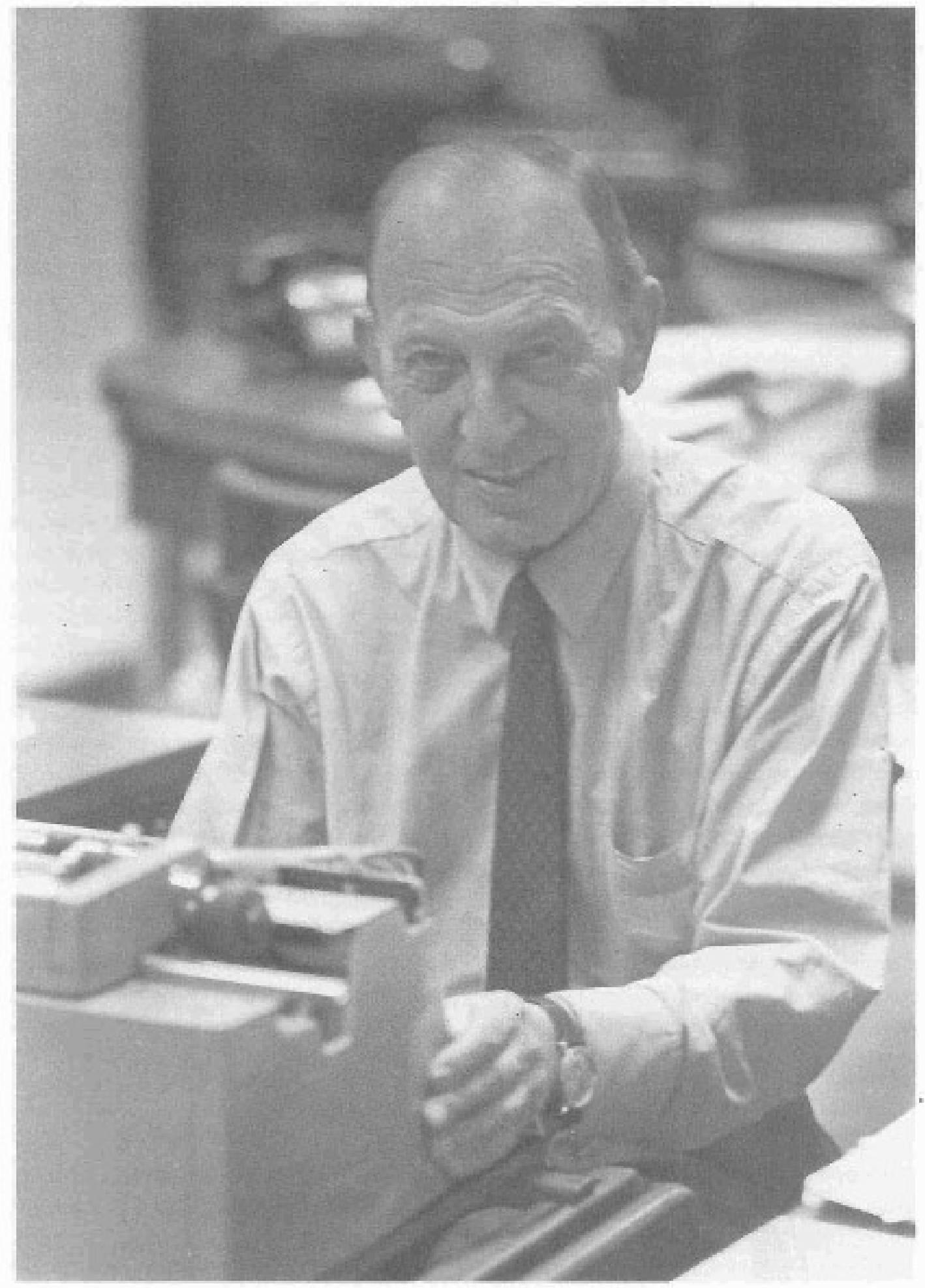

Figure 25. Carroll at his desk at the Montreal Gazeite, late 1950 s. 
(Fig. 25). Once in a while, Carroll got MacLennan hockey tickets. Another McGill friend, Professor Raymond Boyer, wrote asking him to resolve a question about baseball rules. When Carroll retired as sports editor in 1969, a reader praised his "informative articles; your tolerant outlook; your comfortable English," which avoided the emotional verbosity of most sports writers. ${ }^{35}$

Carroll's avocations of journalism, fiction and sports fused in his McGill novel, particularly in Coach Connelly, the only important character obviously drawn from life, based on Shag Shaughnessy. Carroll immortalized Shaughnessy nonfictionally as well. In 1951 he tabulated Shaughnessy's contributions to Canadian and McGill football: how Shaughnessy had taught McGill players organized line play instead of haphazard blocking to open a hole for the ball carrier; taught two on one blocking; established a two man secondary defence line; and introduced the split buck, and formations which were "simple devices for putting into effect Napoleon's theory of winning battles: 'Get the most men at the right place at the right time.,"'36 At Shaughnessy's death in 1969, Carroll summed up his profound influence on Canadian football: "He was the first coach in Canada to use linebackers, the huddle and the unbalanced line. He persuaded the rule makers to drop the side-scrims and reduce the number of players on a team from 14 to 12 , to adopt the direct pass from centre instead of heeling the ball out, and to open up the game by extending the blocking zone... 'Football is a team game and any rule that prevents a player from helping a teammate advance the ball is a bad rule, he [Shaughnessy] pointed out .... Any rule that opens up the game and reduces the risk of injury is a good rule."'37

In Carroll's love of football and impressions of Shaughnessy lie the beginnings of this McGill novel and Carroll's sports writing career. Carroll might have liked the idea that his life imitated his fiction and vice versa.

35 Paul Rimstead's column, The Toronto Sun, 10 Nov. 1980, 5; several items, 1950s, file 10, "MacLennan", Carroll Papers, MG4151, C4 - MacLennan mentions, 15 April 1950, that he is busy finishing a novel, but suggests lunch in a few weeks; undated letter, file 12, "Boyer", MG 4151, C4; letter from E.B. Anderson to Carroll, 11 November 1969, Correspondence, MG4151, C.6.

36 Dink Carroll, "Frank Shaughnessy - Football Pioneer," The MCGill News (Fall 1951), 18-19, 21. Cameo real characters in Carroll's novel include Major Forbes, Leacock, and perhaps the waiters at the Pig; and - unnamed - Currie, Beatty, and Willingdon.

37 Carroll, Obituary for Shaughnessy, The McGill News, luly 1969, 32. Besides inventing new strategies, Shaughnessy wanted a controlled environment for players during the season. During Carroll's McGill days, Shaughnessy advocated not only a training table but also a team residence. Writing about the 1922 season (in Old McGill 1924, 79) Shaughnessy lamented: "We have no dormitories at McGill. Therefore a college spirit brought about by constant association is lost. The greatest incentive to development of college spirit is to have men eat and sleep together.... A fighting Won't-be-beaten football team is a wonderful inspiration to any college. We can have that team at McGill and it is worth every sacrifice to obtain it." By the 1923 season, just after Carroll left, Shaughnessy established a "Dormitory" for the football squad in the new addition to the field house and declared: "It was apparent that there was a better feeling in the squad than had existed in a long time. The men slept and ate together, played together, were able to talk football at all times, and I know would have fought for each other" (Old McGil/ 1925, 221). Their duties on the football field done, his players would go on to win the battles of life. 


\section{NOTES ON THE MANUSCRIPT} OF CARROLL'S MCGILL NOVEL

\section{PHYSICAL DESCRIPTION}

This untitled, undated, unfinished, unpublished typescript novel set at McGill is held by the McGill University Archives in the Austin "Dink" Carroll Papers, MG 4151, C2. It was received from Carroll's widow Peggy Carroll with other papers of Carroll's, including correspondence from Morley Callaghan, in 1991, under the Archives' mandate to acquire private records from McGill's staff, graduates and English-Montreal milieu. While extensive (114 pages), the novel is incomplete with no denouement. It was more likely unfinished than partly lost, as Carroll saved his unpublished fiction. In the brief prologue and sequel, Carroll called his protagonist Peter Rush; the protagonist of the 100 page main body is called Peter Rice. The sequential order of the manuscript is as follows. The prologue "Chapter 1" describes protagonist "Peter Rush" at school in Ontario, hoping to attend McGill; it consists of 4 pages paginated 1 to 4 . "Chapter 2" (with the protagonist's name changed to Peter Rice) begins with a new page 1. At page 6 , there begins chapter "II." Thence pagination continues consecutively from page 6 to page 100 , which concludes chapter "XII" and the narrative of Peter Rice's first year at McGill. There follows an additional 10 pages, paginated 1 to 10 , of a second year sequel (with the protagonist's name back to Peter Rush). The prologue and sequel fragments may have been written together to flesh out the narrative of Peter's first year.

The manuscript at McGill Archives is typed (original, top copy), apparently a first draft, with handwritten revisions, on one side of standard 28 X $22.5 \mathrm{~cm}$ paper, 114 pages in total. There seems little or no variation in the typeface so presumably the typescript was not typed over long intervals. Carroll composed it with his other work at a typewriter. Excusing a handwritten letter, ca. 1935, to Peggy Porter, he notes it is the first time he's used a pen in months - "the typewriter has a way of making longhand a painful exercise." (undated, Carroll Papers, MG 4151, C.5). Carroll inscribed about 300 minor handwritten revisions, changing words or phrases but rarely the purport and never the plot. In the few quotations where a choice had to be made between the original or the amended phrase, I chose the version which best expressed Carroll's direct style This article quotes about 18 to 20 per cent of the manuscript.

\section{DATE OF PLOT AND DATE OF WRITING}

The typescript and story itself contain no dates. Internal evidence places the plot over either the academic year September 1927 to May 1928 or 1928 to 1929. This is later than 1920-1923, when Carroll attended McGill. The main clues for the date are that Peter Rice, arriving at McGill, sees the Roddick (Gates (not put up until 1925). A 1927-1928 date is suggested by Peter's reference to the "talkies" in the cinema as just introduced (1927); either 1927-1928 or 1928-1929 are indicated by the McGill Centennial of 1921 having been "six or seven years" earlier; but 1928-1929 is indicated if emphasis is given to Peter's team winning the championship, which McGill actually won in 1928 (pp.3, 67,41-43).

Consequently, the novel could not have been written until after 1927. More likely, Carroll wrote it in the mid-1930s when he wrote much of his other fiction. To hazard a guess, it may have been written before most of his other surviving fiction; while perhaps more ambitious, the style is less succinct and confident than that of his short stories. The Carroll archive includes a few short fiction typescripts that appear to have been sent to publications or agents (Maxim Lieber, for one, in 1935) and later stored in envelopes, mostly with 1930 s postmarks. In letters in 1935 to his future wife Margaret Porter, Carroll mentioned that he was writing stories and articles and showing some of them to Morley Callaghan. Carroll may have been thinking of his own college novel when he suggested (ca. 1935?) that an acquain- 
tance who wants to be a writer might profit by going to university: "he might even write undergraduate stories." (Carroll Papers, MG 4151, C4, file 9: several letters lacking year-dates, preserved in envelopes postmarked 1935). The attitudes expressed in the novel seem to date from no later than the 1930s. The world affairs discussion about the Empire, Canada's youthfulness, and Japan's hatred of the U.S. sound like they predate the Second World War - as does Tony Dodds's longing for the food and women of Germany and Austria (p.61). The simplest explanation for Carroll's setting his novel in 1927 or 1928 may be that he wrote it about then. In any event, it was almost certainly written before the outbreak of war in 1939, given the rest of the indications.

Carroll had several reasons to shift the date from his own early 1920 s at McGill to the later 1920s. Like many writers, he may have wanted to distance his own experiences from his protagonist's invented ones. As well, McGill itself became more imposing after the reconstruction in 1925 of the Arts Building and the building of the Roddick Gates (and a few other buildings as well as Zeta Psi's new house). More important, a later time let Carroll introduce his current ideas rather than remembered ones. He also could use the "Aesthetes," modelled on the McGill Group, active from 1925 to 1927 . In sum, the late 1920 s may have looked like a richer, more interesting time, as McGill absorbed the Fitzgerald college ethos of parties and prosperity, before the Crash and Depression hit in 1929

\section{SOURCES OF THE ILLUSTRATIONS}

Figure 1. Old McGill 1930: 3. Another image of the Gates of McGill - the Roddick Gates appears on the cover of this issue of Fontanus: by A. Cloutier, for the cover of The Passing Show (Montreal), 3, no. 12, September 1929.

Figure 2. Published McGill football programme, undated, with Sir Arthur Currie's photograph on the cover. Artist: Percy Nobbs? Carroll Papers, MG 4151, C3, file 8: booklets.

Figure 3, Old McGill 1928: 103.

Figure 4. Published McGill football programme, undated, with Sir Arthur Currie's photograph on the cover. Carroll Papers, MG 4151, C3, file 8: booklets.

Figure 5. McGill University Archives Photograph Collection, PR008963, cropped, photographer unknown, ca. 1921. Published in Old McGill. 1924: 176; a published print is also in the Carroll Papers, MG4151, C5, file: correspondence 1950-54.

Figure 6. Published photograph, provenance unclear. Carroll Papers, MG 4151, C3, file 6: clippings.

Figure 7. Old McGill 1927: 301.

Figure 8. Published photograph (twinned with that of Figure 6), provenance unclear. Carroll Papers, MG 4151, C3, file 6: clippings.

Figure 9. The listening Post (Montreal), 1, no. 1, February 1923: 7.

Figure 10. Wilfrid Bovey, "McGill and her Builders", Canadian Magazine, 63, no. 7, November 1924: 388.

Figure 11. McGill Centennial Endowment brochures, ca. 1921. Artist unknown, McGill University Archives, RG 49, C111.

Figure 12. Old McGill 1928: 23.

Figure 13. Old McGill 1923: 155.

Figure 14. Programme cover, Red and White Revue, 1926. Artist unknown, McGill University Archives, RG 75, C91. 
Figurc is. Programme cover, Nount Reyal Hote: .Mc rill Vight at the St. Denis Theatre, 1924. Arrist unknown, Mc(rill Lniversiry Aicinives, $R 675, C 91$.

Figure 16. Old MiGill 1931: facing 166.

"igure 17. Old MeGill 1929: 163.

Figure 18. Ola MCLill 1928: 47 .

Figure 19. Oll McGill 1923: :09.

Higure 20. Old MCGill 1921: 284.

Figure 21. Olal MCCill 1928: 6.

Eigure 22. Old MiGill: a Year Book of Undergraduate Activities at the University, Vol. XXXIL, MCUXXIX: frontispice. Photographer's name illegiblc Uas. Bacon?). This book is not to be confused with Old MiGill 1929, published by the Junior Year, MCMXXVIII, VOL. XXXI.

Figure 23. Oid MClibl 2928: 252.

Figure 24. Pubiished McGill tootbal! programme with Currie's photogiaph on the cover, Carroll Papers, MCi 4151, C.3, file 6: clippings.

Figure 25. 8EWi pinotograph, photogrâpher uminown, Carroll Papers, $\mathrm{MG}$ 415), (.2, file 8: photos.

\section{ACKNOWLEDGEMEN'TS}

I owe thanks to the late Peggy Carroll for giving the papers of her husoand Dink Cariol: to the McGill Lniversity Archives in 1991 (where I was archivist for historical records); to Michael Carroll, QC, Carroll's son, for permission to quote from bis tather's unpublished novel; to Ann Carroll (Mrs. Michael Carroll); Carol Wiens, Librarian, Montreal Neurological Institute/Hospital; Michael Porritt. The Montreal Gazette; Judith Nefsky, Archivist, Canadian Pucific, Montreal; David Rosc, Nonteal architeccural witer; Pamela Miller of the Osier Library and Eari Lukeman of McGill's Department of Athletics; and Gordon Burr of the MCGill University Archives and jobanne Pelletier, David Poliak, Glenn Brown, Gerry Castleman and all the Archives staff, Elizabcth Shearon and Montague Cohen, Editor, Fontunus, and Lonnie Weatherby and David McKnight of the McGill Libraries. For biographical information on Carroll, Ihave relied mainly on the accounts by Carroll's fellow joumalists cited in the notes. I have profited from artworks and photographs ro illustrate this article; the creators are identified where possible. The illustrations, many by bcGill architecture siudents, offer a sample of the fine drawings to be found in issues of Oid MCGill, cspecially between 1920 and 1940 . 